\title{
PEFERENCE
}

Allu b 690374

NBSIR 74.635

Method of Testing for Rating Solar Collectors Based on Thermal Performance

James E. Hill

Tamami Kusuda

Thermal Engineering Systems Section

Center for Building Technology

National Bureau of Standards

Washington, D. C. 20234

December 1974

Interim Report

Prepared for

National Science Foundation

${ }^{4} 800$ G Street

$-Q 0$

ashington, D. C. 20550 


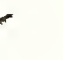


NBSIR 74-635

\section{METHOD OF TESTING FOR RATING SOLAR COLLECTORS BASE ON THERMAL} PERFORMANCE

James E. Hill

Tamami Kusuda

Thermal Engineering Systems Section

Center for Building Technology

National Bureau of Standards

Washington, D. C. 20234

December 1974

Interim Report

Prepared for

National Science Foundation

1800 G Street

Washington, D.C. 20550

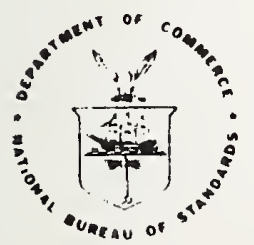

U. S. DEPARTMENT OF COMMERCE, Frederick B. Dent, Secretary 

Method of Testing for Rating Solar Collectors

Based on Thermal Performance

\author{
James E. Hill and Tamami Kusuda \\ Thermal Engineering Systems Section \\ Center for Building Technology \\ National Bureau of Standards \\ Washington, D. C. 20234
}

ABSTRACT

The National Bureau of Standards has made a study of the different techniques that could be used for testing solar collectors and rating them on the basis of thermal performance. This document outlines a proposed standard test procedure based on that study. It is written in the format of a standard of the American Society of Heating, Refrigerating, and Air Conditioning Engineers and specifies the recommended apparatus, instrumentation, and test procedure.

Key Wurds: Solar collector; standard test; thermal performance; solar energy; standard; solar radiation. 
SECTION 1. PURPOSE . . . . . . . . . . . . . . 1 SECTION 2. SCOPE . . . . . . . . . . . . . . 1 SECTION 3. DEFINITIONS ..................... 2 SECTION 4. CLASSIFICATIONS ...................... 4 SECTION 5. REQUIREMENTS ................... 5 SECTION 6. INSTRUMENTATION . . . . . . . . . . 6 SECTION 7. APPARATUS AND METHOD OF TEST ING . . . . . . . 11 SECTION 8. TEST PROCEDURE AND CALCULATIONS . . . . . . . . 17 SECTION 9. DATA TO BE RECORDED AND TEST REPORT . . . . . . 25 SECTION 10. NOMENCLATURE . . . . . . . . . . . . 25 SECTION 11. REFERENCES .................. 27 TABLES ............................ 30 FIGURES . . . . . . . . . . . . . . 4 46 
1.1 The purpose of this standard is to provide test methods for determining the thermal performance of solar collectors which heat fluids and are used in systems to provide the thermal requirements for heating, cooling, and the generation of domestic hot water in buildings.

\section{SECTION 2. SCOPE}

2.1 This standard applies to solar collectors in which a fluid enters the device through a single inlet and leaves the device through a single outlet. The collector containing more than one inlet and/or outlet can be tested according to this standard provided that the external piping can be connected in such a way as to effectively provide a single inlet and/or out let for the determination of the bulk properties of the fluid entering and leaving the collector. The fluid can be either a gas or liquid but not a mixture of the two. The collector can be a concentrating collector provided that the aperture or interception area for the device can be determined. The collector may have the capability of rotating so as to track the sun.

2.2 This standard is not applicable to those configurations in which the flow into the collector and out of the collector cannot be reduced effectively to one inlet and one outlet. This standard is not applicable to those collectors in which the thermal storage unit is an integral part of the collector such that the collection process and storage process cannot be separated for the purpose of making measurements.

2.3. This standard does not address factors relating to cost or consideration of requirements for interfacing with a specific heating and cooling system.

2.4 The present version of the standard provides test methods for determining the steady-state efficiency of solar collectors. The transient response of solar collectors cannot be determined with the test methods outlined herein. 


\section{SECTION 3. DEFINITIONS}

3.1 AMBIENT AIR

Ambient air is the outdoor air in the vicinity of the solar collector being tested.

\subsection{ABSORBER}

The absorber is that part of the solar collector that receives the: incident solar radiation and transforms it into thermal energy. It is usually a solid surface through which energy is transferred to the transfer fluid; however, the transfer fluid itself could be the absorber in the case of a "black liquid".

\subsection{APERTURE}

The aperture is the opening or projected area of a solar collector through which the unconcentrated solar energy is admitted and directed to the absorber.

\subsection{CONCENTRATING COLLECTOR}

A concentrating collector is a solar collector that contains reflectors, lenses, or other optical elements to concentrate the energy falling on the aperture onto a heat exchanger of surface area smaller than the aperture.

\subsection{CONCENTRATOR}

The concentrator is that part of a concentrating collector which directs the incident solar radiation onto the absorber.

\subsection{COVER PLATE}

The cover plate designates the diathermanous material or materials covering the aperture and most directly exposed to the solar radiation. These materials are generally used to reduce the heat loss from the absorber to the surroundings and to protect the absorber.

\subsection{FLAT-PLATE COLLECTOR}

A flat-plate collector is a solar collector in which the solid surface absorbing the incident solar radiation is essentially flat and employs no concentration. 
Gross cross-sectional area is the overall or outside area of a flat-plate collector. It is usually slightly larger than the absorber area since it includes the framework required to hold the absorber.

\subsection{INCIDENT ANGLE}

The incident angle is the angle between the sun's rays and the outward drawn normal from the solar collector.

\subsection{INSOLATION}

Insolation is the rate of solar radiation received by a unit surface area in unit time $\left(\mathrm{W} / \mathrm{m}^{2}, \mathrm{Btu} /\left(\mathrm{h} \cdot \mathrm{ft}^{2}\right)\right)$.

\subsection{INSTANTANEOUS EFFICIENCY}

The instantaneous efficiency of a solar collector is defined as the amount of energy removed by the transfer fluid per unit of transparent frontal area over a given 15 minute period divided by the total incident solar radiation onto the collector per unit area for the 15 minute period.

\subsection{INTEGRATED AVERAGE INSOLATION}

The integrated average insolation is the total energy per unit area received by a surface for a specified time period divided by the time period $\left(\mathrm{W} / \mathrm{m}^{2}, \mathrm{Btu} /\left(\mathrm{h} \cdot \mathrm{ft} \mathrm{t}^{2}\right)\right)$.

\subsection{PYRANOMETER}

A pyranometer is a radiometer used to measure the total incident solar energy per unit time per unit area upon a surface which includes the beam radiation from the sun, the diffuse radiation from the sky, and the shortwave radiation reflected from the foreground.

\subsection{PYRHELIOMETER}

A pyrheliometer is a radiometer used to measure the direct or beam radiation on a surface normal to the sun's rays. 
Quasisteady is the term used in this document to describe the state of the solar collector test when the flow rate and temperature of the fluid entering the collector is constant but the exit fluid temperature changes "gradually" due to the normal change in insolation that occurs with time for clear sky conditions.

\subsection{SOLAR COLLECTOR}

A solar collector is a device designed to absorb incident solar radiation and to transfer the energy to a fluid passing in contact with it.

\subsection{TOTAL INCIDENT INSOLATION}

Total incident insolation is the total energy received by a unit surface area for a specified time period $\left(\mathrm{J} / \mathrm{m}^{2}\right)$.

\subsection{TRANSFER FLUID}

The transfer fluid is the medium such as air, water, or other fluid which passes through or in contact with the solar collector and carries the thermal energy away from the collector.

\subsection{TRANSPARENT FRONTAL AREA}

The transparent frontal area is the area of the transparent frontal surface for flat-plate collectors.

\subsection{STANDARD AIR}

Standard air is air weighing $1.2 \mathrm{~kg} / \mathrm{m}^{3}\left(0.0751 \mathrm{~b} / \mathrm{ft}^{3}\right)$, and is equivalent in density to dry air at a temperature of $21.1^{\circ} \mathrm{C}\left(70^{\circ} \mathrm{F}\right.$ ) and a barometric pressure of $1.01 \times 105 \mathrm{~N} / \mathrm{m}^{2}(29.92$ in of $\mathrm{Hg}$ )

\section{21 STANDARD BAROMETRIC PRESSURE}

$1.01 \times 10^{5} \mathrm{~N} / \mathrm{m}^{2}(29.92 \mathrm{in.}$ of $\mathrm{Hg})$

\section{SECTION 4. CLASSIFICATIONS}

4.1 Solar collectors may be classified according to their collecting characteristics, the way in which they are mounted, and the type of transfer fluid they employ. 
4.1.1 Collecting Characteristics. A non-concentrating or "flatplate" collector is one in which the absorbing surface for solar radiation is essentially flat with no means for concentrating the incoming solar radiation. A concentrating or "focusing" collector is one which usually contains reflectors or employs other optical means to concentrate the energy falling on the aperture onto a heat exchanger of surface area smaller than the aperture.

4.1.2 Mounting. A collector can be mounted to remain stationary, be adjustable as to tilt angle (measured from the horizontal) to follow the change in solar declination, or be designed to track the sun. Tracking is done by employing either an equatorial mount or an altazimuth mounting, for the purpose of increasing the absorption of the daily solar irradiation.

4.1.3 Type of Fluid. A collector will usually use either a liquid or a gas as the transfer fluid. The most common liquids are water or a water-ethylene glycol solution. The most common gas is air.

\section{SECTION 5. REQUIREMENTS}

5.1 Solar collectors shall be tested for rating in accordance with the provisions set forth below and in Section 8 .

5.1.1 The size of collector tested shall be large enough so that the performance characteristics determined will be indicative of those that would occur when the collector is part of an installed system. If the collector is modular and the test is being done on one module, it should be mounted and insulated in such a way that the back and edge losses will be characteristic of those that will occur during operation on a structure.

5.1.2 The collector shall be mounted in a location such that there will be no significant energy reflected or reradiated onto the collector from surrounding buildings or any other surfaces in the vicinity of the test stand for the duration of the test(s). This will be satisfied if the ground and immediately adjacent surfaces are diffuse with a reflectance of less than 0.20. If significent reflection will occur, provision shall be made to shield the collector by the use of a non-reflective shield. In addition, the test stand shall be located so that a shadow will not be cast onto the collector at any time during the test period. 
5.1.3 The test(s) shall be conducted on days having weather conditions such that the 15 minute integrated average insolation measured in the plane of the collector or aperture, reported, and used for the computation of instantaneous efficiency values shall be a minimum of $630 \mathrm{~W} / \mathrm{m}^{2}(199.8 \mathrm{Btu} /($ h. $\left.\left.\mathrm{ft}^{2}\right)\right)$. Specific values that can be expected for clear sky conditions are shown in Tables Al through A6 taken from reference [1]. More accurate estimates can be made using the tables in conjunction with clearness numbers*.

5.1.4 The orientation of the collector shall be such that the incident angle (measured from the normal to the collector surface or aperture) is less than $45^{\circ}$ during the period in which test data is being taken. Angles of incidence can be estimated from Tables A7 through Al2 taken from reference [2]. More accurate estimates can be made using the procedures out lined in references [3], p. 393 or [4], pp. 283292 .

5.1.5 The air velocity across the collector surface of a flatplate collector or aperture of a concentrating collector during the test (s) shall be measured. The measurement shall be made at a distance of approximately $1 \mathrm{~m}$ (3.3 ft) from the collector along the direction it faces and at a height corresponding to the center of the collector panel.

5.1.6 The range of ambient temperatures for all reported test points comprising the "efficiency curve" shall be less than $30^{\circ} \mathrm{C}\left(54^{\circ} \mathrm{F}\right)$.

5.1.7 The transfer fluid used in the solar collector shall have a known specific heat which varies by less than $0.5 \%$ over the temperature range of the fluid during a particular 15 minute test period.

\section{SECTION 6. INSTRUMENTATION}

\subsection{SOLAR RADIATION MEASUREMENT}

6.1.1 A pyranometer shall be used to measure the total short-wave radiation from both the sun and the sky. The instrument shall have the following characteristics [5]:

*

Reference [3], p. 394, Figure 4. 
6.1.1.1 Change of Response Due to Variation in Ambient Temperature. The instrument shall either be equipped with a built-in temperature compensation circuit and have a temperature sensitivity of less than \pm 1 percent over the range of ambient temperature encountered during the test(s) or have been tested in a temperature-controlled chamber over the same temperature range so that its temperature coefficient has been determined in accordance with reference [5].

6.1.1.2 Variation in Spectra1 Response. Errors caused by a departure from the required spectral response of the sensor shall not exceed \pm 2 percent over the range of interest*.

6.1.1.3 Nonlinearity of Response. Unless the pyranometer was supplied with a calibration curve relating the output to the insolation, its response shall be within \pm 1 percent of being linear over the range of insolation existing during the tests.

6.1.1.4 Time Response of Pyranometer. The time constant of the pyranometer shall be less than $5 \mathrm{~s}$.

6.1.1.5 Variation of Response With Attitude. The calibration factor of a pyranometer can change when the instrument is used in other than the orientation for which it was calibrated. The instruments' calibration factor (including corrections) sha11 change less than \pm 0.5 percent compared with the calibrated orientation when placed in the orientation used during the test(s).

6.1.1.6 Variation of Response With Angle of Incidence. Ideally the response of the receiver is proportional to the cosine of the zenith angle of the solar beam and is constant at a 11 azimuth angles. The pyranometer's deviation from a true cosine response shall be less than \pm 1 percent for the incident angles encountered during the test $(\mathrm{s})$.

*

Pyranometer thermopiles which are "all black" and which are coated with Parson's black or 3M $101 \mathrm{C} 10$ velvet black paint and which have selected optical grade hemispheres usually satisfy this requirement [5]. Note: Identification of commercial materials does not imply recommendation or endorsement by the National Bureau of Standards. 
6.1.2 The pyranometer shall be calibrated within six months of the collector test(s) against other pyranometers whose calibration uncertainty relative to recognized measurement standards is known*.

\subsection{TEMPERATURE MEASUREMENTS}

6.2.1 Temperature measurements shall be made in accordance with ASHRAE Standard 41-66, Part 1 [6].

6.2.2 Temperature Difference Measurements Across the Solar Co1lector. The temperature difference of the transfer fluid across the solar collector shall be measured with:

a. Thermopile (air or water as the transfer fluid)

b. Calibrated resistance thermometers connected in two arms of a bridge circuit (only when a liquid is the transfer fluid)

6.2.3 The accuracy and precision of the instruments and their associated readout devices shall be within the limits as follows :

Instrument Accuracy*\% Instrument Precision**\%

Temperature

$$
\begin{aligned}
& \pm 0.5^{\circ} \mathrm{C}\left( \pm 0.9 \mathrm{OF}^{\circ}\right) \\
& \pm 0.1{ }^{\circ} \mathrm{C}( \pm 0.2 \mathrm{O})
\end{aligned}
$$$$
\pm 0.2{ }^{\circ} \mathrm{C}\left( \pm 0.4{ }^{\circ} \mathrm{F}\right)
$$

Temperature

Difference

$\pm 0.1^{\circ} \mathrm{C}\left( \pm 0.2^{\circ} \mathrm{F}\right)$

*

One nationally recognized calibration center is the Eppley Laboratory in Newport, Rhode Island. The calibration data are commonly expressed in cal/( $\mathrm{cm}^{2}$. min) or in langleys/min. In some meteorological services, calibration data are supplied in milliwatt $/ \mathrm{cm}^{2}$. The following equivalent units sha11 be used:

$$
\begin{aligned}
& 1 \mathrm{cal} /\left(\mathrm{cm}^{2} \cdot \min \right)=11 \mathrm{y} / \mathrm{min}=.001434 \mathrm{~W} / \mathrm{m}^{2} \\
& 1 \mathrm{~mW} / \mathrm{cm}^{2}=0.1 \mathrm{~W} / \mathrm{m}^{2}
\end{aligned}
$$

$* *$

The ability of the instrument to indicate the true value of the measured quantity.

$* * *$

Closeness of agreement among repeated measurements of the same physical quantity. 
6.2.4 In no case should the smallest scale division of the instrument or instrument system exceed $21 / 2$ times the specified precision. For example, if the specified precision is $t$ $0.1{ }^{\circ} \mathrm{C}\left( \pm 0.2^{\circ} \mathrm{F}\right)$, the smallest scale division shall not exceed $0.25^{\circ} \mathrm{C}\left(0.5^{\circ} \mathrm{F}\right)$.

6.2.5 The instruments shall be configured and used in accordance with Section 7 . of this standard.

6.2.6 When using thermopiles, they shall be constructed in accordance with ANSI Standard C96.1-1964 (R 1969) [7].

\subsection{LIQUID FLOW MEASUREMENTS}

6.3.1 The accuracy of the liquid flow rate measurement using the calibration, if furnished shall be equal to or better than $\pm 1.0 \%$ of the measured value.

\subsection{INTEGRATORS AND RECORDERS}

6.4.1 Strip chart recorders used shall have an accuracy equal to or better than $\pm 0.5 \%$ of the temperature difference and/or voltage measure $\vec{d}$ and have a time constant of 1 s or less.

6.4.2 Electronic integrators used shall have an accuracy equal to or better than $\pm 1.0 \%$ of the measured value.

\subsection{AIR FLOW MEASUREMENTS}

When air is used as the transfer fluid, air flow rate shall be determined as described in Section 7.

\subsection{PRESSURE MEASUREMENTS}

6.6.1 Nozzle Throat Pressure. The pressure measurement at the nozzle throat shall be made with instruments which shall permit measurements of pressure to within $\pm 2.0 \%$ absolute and whose smallest scale division shall not exceed 2 1/2 times the specified accuracy [11]. 
6.6.2 Air Flow Measurements. The static pressure across the nozzle and the velocity pressure at the nozzle throat shall be measured with manometers which have been calibrated to have an accuracy to within $\pm 1.0 \%$ of the reading. The smallest manometer scale division shall not exceed $2.0 \%$ of the reading $[11\rceil$.

6.6.3 Pressure Drop Across Collector. The static pressure drop across the solar collector shall be measured with a manometer having an accuracy of $2.49 \mathrm{~N} / \mathrm{m}^{2}(0.01 \mathrm{in}$. of water).

6.7 TIME AND MASS MEASUREMENTS

Time measurements and mass measurements shall be made to an accuracy of $\pm 0.20 \%[11]$.

\subsection{WIND VELOCITY}

The wind velocity shall be measured with an instrument and associated readout device that can determine the integrated average wind velocity for each 15 minute test period to an accuracy of \pm 0.08 $\mathrm{m} / \mathrm{s}(1.8 \mathrm{mph})$. 


\subsection{LIQUID AS THE TRANSFER FLUID}

The test configuration for the solar collector employing liquid as the transfer fluid is shown in Figure $\mathrm{Al}$.

7.1.1 Solar Collector. The solar collector should be mounted in its rigid frame at the predetermined tilt angle (for stationary collectors) or movable frame (for movable collectors) and anchored rigidly enough to a foundation so that the collector can hold its selected angular position against a strong gust of wind.

7.1.2 Ambient Temperature. The ambient temperature sensor shall be housed in a well-ventilated instrumentation shelter with its bottom $1.25 \mathrm{~m}$ ( $4.1 \mathrm{ft}$ ) above the ground and with its door facing north, so that the sun's direct beam cannot fall upon the sensor when the door is opened. The instrument shelter shall be painted white outside and shall not be closer to any obstruction than twice the height of the obstruction itself (i.e., trees, fences, buildings, etc.) [15].

7.1.3 Pyranometer. The pyranometer shall be mounted on the surface parallel to the collector surface in such a manner that it does not cast a shadow onto the collector plate. Precautions should be always taken to avoid subjecting the instrument to mechanical shocks or vibration during the installation. The pyranometer should be oriented so that the emerging leads or the connector are located north of the receiving surface (in the Northern Hemisphere) or are in some other manner shaded. This minimizes heating of the electrical connections by the sun.

Care should also be taken to minimize reflected and reradiated energy from the solar collector onto the pyranometer. Some pyranometers come supplied with shields. This should be adjusted so that the highest point on the shield lies parallel to and just below the plane of the thermopile. Some pyranometers not supplied with a shield may be susceptible to error due to reflections by radiation that originates below the plane of the thermopile. Precautions can be taken by constructing a cylindrical shield, the top of which should be coplaner with the thermopile [5].

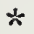

The recommended apparatus consists of a closed loop configuration. An open loop configuration is an acceptable alternative provided that the test conditions specified herein can be satisfied. 
7.1.4 Temperature Measurement Across the Solar Collector. The temperature difference of the transfer fluid between entering and leaving the solar collector shall be measured using either two calibrated resistance thermometers connected in two arms of a bridge or a thermopile made from calibrated, type $\mathrm{T}$ thermocouple wire all taken from a single spool. The thermopile shall contain any even number of junctions constructed according to the recommendations in reference [7]. Each resistance thermometer or each end of the thermopile is to be inserted into a well [8] located as shown in Figure A1. To insure good thermal contact, the wells shall be filled with light oil. The wells should be located just downstream of a right angle bend to insure proper mixing [6].

To minimize temperature measurement error, each probe should be located as close as possible to the inlet or outlet of the solar collector device. In addition, the piping between the wells and the collector shall be insulated in such a manner that the calculated heat loss or gain from the ambient air would not cause a temperature change for any test of more than $0.05^{\circ} \mathrm{C}\left(0.09^{\circ} \mathrm{F}\right)$ between each well and the collector.

7.1.5 Additional Temperature Measurements. The temperature of the transfer fluid at the two positions cited above shall also be measured by inserting appropriate sensors into the wells. Reference [6] should be followed in making these measurements.

7.1.6 Pressure Drop Across the Solar Collector. The pressure drop across the solar collector shall be measured using static pressure tap holes and a manometer. The edges of the holes on the inside surface of the pipe should be free of burrs and should be as small as practicable and not exceeding $1.6 \mathrm{~mm}$ (1/16 inch) diameter [12]. The thickness of the pipe wall should be $21 / 2$ times the hole diameter [12].

7.1.7 Reconditioning Apparatus. As shown in Figure Al, a heat exchanger is used to cool the transfer fiuid to simulate the building load and an adjustable electric resistance heater is used to control the inlet temperature to the prescribed test value. This combination of equipment or equivalent shall control the temperature of the fluid entering the solar collector to within $\pm 0.5^{\circ} \mathrm{C}\left( \pm 0.9^{\circ} \mathrm{F}\right)$ at all times during the tests.

7.1.8 Additiona1 Equipment. A pressure gauge, a pump, and a means of adjusting the flow rate of the transfer fluid shall be provided at the relative locations shown in Figure A1. Depending upon the test apparatus design, an additional throttle valve may be required in the line just preceding the solar collector for proper control. An expansion tank and 
a pressure relief valve should be installed to allow the transfer fluid to freely expand and contract in the apparatus*. In addition, filters should be installed within the apparatus as well as a sight glass to insure that the transfer fluid passing through the collector is free of contaminants including air bubbles.

\subsection{AIR AS THE TRANSFER FLUID}

The test configuration for the solar collector employing air as the transfer fluid is shown in Figure A2**.

7.2.1 Solar Collector. The solar collector should be mounted in its rigid frame at the predetermined tilt angle (for stationary collectors) or movable frame (for movable collectors) and anchored rigidly enough to a foundation so that the collector can hold its selected angular position against a strong gust of wind.

7.2.2 Ambient Temperature. The ambient temperature sensor shall be housed in a wel1-ventilated instrumentation shelter with its bottom $1.25 \mathrm{~m}$ ( $4.1 \mathrm{ft}$ ) above the ground and with its door facing north, so that the sun's direct beam cannot fall upon the sensor when the door is opened. The instrument shelter shall be painted white outside and shall not be closer to any obstruction than twice the height of the obstruction itself (i.e., trees, fences, buildings, etc.) [15] .

7.2.3 Pyranometer. The pyranometer shall be mounted on the surface parallel to the collector surface in such a manner that it does not cast a shadow onto the collector plate. Precautions should be always taken to avoid subjecting the iastrument to mechanical shocks or vibration during the installation. The pyranometer should be oriented so that the emerging leads or the connector are located north of the receiving surface (in the Northern Hemisphere) or are in some other manner shaded. This minimizes heating of the electrical connections by the sun.

$*$

Figure Al should not be interpreted to mean that the relief valve and expansion tank necessarily be located below the solar collector.

$* x$

The recommended apparatus consists of a closed loop configuration. An open loop configuration is an acceptable alternative provided that the test conditions specified herein can be satisfied. 
Care should also be taken to minimize reflected and reradiated energy from the solar collector onto the pyranometer. Some pyranometers come supplied with shields. This should be adjusted to be parallel to and to lie just below the plane of the thermopile. Some pyranometers not supplied with a shield may be susceptible to error due to reflections by radiation that originates below the plane of the thermopile. Precautions can be taken by constructing a cylindrical shield, the top of which should be coplaner with the thermopile [5].

7.2.4 Test Ducts. The air inlet duct, between the air flow measuring apparatus and the solar collector, shall have the same cross-sectional dimensions as the inlet manifold to the solar collector. The air outlet duct, between the solar collector and the reconditioning apparatus, shall have the same cross-sectional dimensions as the outlet manifold from the solar collector*.

7.2.5 Temperature Measurement Across the Solar Collector. A thermopile shall be used to measure the difference between the inlet air temperature and outlet air temperature of the solar collector. It shall be constructed from calibrated type $\mathrm{T}$ thermocouple wire all taken from a single spool. No extension wires are to be used in either its fabrication or installation. The wire diameter must be no larger than $0.51 \mathrm{~mm}$ (24 AWG) and the thermopile shall be fabricated as shown in Figure A3. There shall be a minimum of six junctions in the air inlet test duct and six junctions in the air outlet test duct. These junctions shall be located at the center of equal cross-sectional areas.

During all tests, the variation in temperature at a given cross section of the air inlet and air outlet test ducts shall be less than $\pm 0.5^{\circ} \mathrm{C}\left( \pm 0.9^{\circ} \mathrm{F}\right)$ at the location of the thermopile junctions. The variation shall be checked prior to testing utilizing instrumentation and procedures outlined in reference [6]. If the variation exceeds the limits above, mixing devices shall be installed to achieve this degree of temperature uniformity. Reference [16] discusses the positioning and performance of several types of air mixers.

The ends of the thermopile should be located as near as possible to the inlet and outlet of the solar collector. The air inlet and air outlet ducts shall be insulated in such a manner that the calculated heat loss or gain to or from the ambient air would not cause a temperature change for any test

The performance of air heaters is expected to be affected by the ductwork entering and leaving the solar collector considerably more so than in the case of solar collectors using a liquid as the transfer fluid. 
of more than $0.05^{\circ} \mathrm{C}\left(0.09^{\circ} \mathrm{F}\right)$ between the temperature measuring locations and the collector.

7.2.6 Temperature Measurements. Sensors and read-out devices meeting the accuracy requirements of Section 6. and giving a continuous reading shall be used to measure the temperature at the locations in the air inlet and air out let ducts shown in Figure A2. Reference [6] should be followed in making these measurements.

7.2.7 Duct Pressure Measurements. The static pressure drop across the solar collector shall be measured using a manometer as shown in Figures $\mathrm{A} 2$ and $\mathrm{A} 4$ [11]. Each side of the manometer shall be connected to four externally manifolded pressure taps on the air inlet and air out let ducts. The pressure taps should consist of $6.4 \mathrm{~mm}$ ( $1 / 4$ inch) nipples soldered to the duct and centered over $1 \mathrm{~mm}$ (0.040 inch) diameter holes. The edges of these holes on the inside surfaces of the ducts should be free of burrs and other surface irregularities [12 1.

7.2.8 Air Flow Measuring Apparatus. Where the air flow rate is sufficiently large, it shall be measured with the nozzle apparatus discussed in Section 7. of reference [11]. As shown in Figure A5, this apparatus consists basically of a receiving chamber, a discharge chamber and an air flow measuring nozzle. The distance from the center of the noz$\mathrm{zle}$ to the side walls shall not be less than $11 / 2$ times the nozzle throat diameter, and the diffusion baffles shall be installed in the receiving chamber at least $11 / 2$ nozzle throat diameters upstream of the nozzle and $21 / 2$ nozzle throat diameters downstream of the nozzle. The apparatus should be designed so that the nozzle can be easily changed and the nozzle used on each test shall be selected so that the throat velocity is between $15 \mathrm{~m} / \mathrm{s}(2960 \mathrm{fpm})$ and $35 \mathrm{~m} / \mathrm{s}$ (6900 fpm). When nozzles are constructed in accordance with Figure $A 6$ and installed in accordance with Section 7.2.9 of this Standard, the discharge coefficient may be assumed to be as follows: 
Reynolds

Number,

$\mathrm{N}_{\mathrm{Re}}$

$$
\begin{array}{r}
20,000 \\
50,000 \\
100,000 \\
150,000 \\
200,000 \\
250,000 \\
300,000 \\
400,000 \\
500,000
\end{array}
$$

Coefficient

of Discharge,

C

0.96

0.97

0.98

0.98

0.99

0.99

0.99

0.99

0.99

If the throat diameter of the nozzle is $0.13 \mathrm{~m}$ (5 in.) or larger, the discharge coefficient may be assumed to be 0.99 . For nozzles smaller than $0.05 \mathrm{~m}$ ( 2 in.) and where a more precise discharge coefficient than given above is desired, the nozzle should be calibrated. The area of the nozzle shall be determined by measuring its diameter to an accuracy of $\pm 0.20 \%$ in four places approximately 45 degrees apart around the nozzle in each of two planes through the nozzle throat, one at the out let and the other in the straight section near the radius [11].

Where the nozzle apparatus is used, an exhaust fan capable of providing the desired flow rates through the solar collector shall be installed in the end wall of the discharge chamber rather than separate from the air flow measuring apparatus as shown in Figure A2. The dry and wet bulb temperature of the air entering the nozzle shall be measured in accordance with reference [6]. The velocity of the air passing through the nozzle shall be determined by either measuring the velocity head by means of a commercially available pitot tube or by measuring the static pressure drop across the nozzle with a manometer. If the latter method is used, one end of the manometer shall be connected to a static pressure tap located flush with the inner wall of the discharge chamber, or preferably, several taps in each chamber should be manifolded to a single manometer. A means shall also be provided for measuring the absolute pressure of the air in the nozzle throat.

Where the air flow rate is sufficiently small so that a nozzle constructed and installed in accordance with the requirements above would have a throat diameter of smaller than $0.025 \mathrm{~m}$ ( 1 in.), the above configuration should not be used and the air flow measuring apparatus as shown in Fig- 
ure A2 should consist of a calibrated flow element* where at least 10 pipe diameters of upstream and downstream pipe section have been included in the calibration**.

7.2.9 Air Leakage. Air leakage through the air flow measuring apparatus, air inlet test duct, the solar collector and the air outlet test duct shall not exceed $\pm 1.0 \%$ of the measured air flow.

7.2.10 Air Reconditioning Apparatus. The reconditioning apparatus shall control the dry bulb temperature of the transfer medium entering the solar collector to within $\pm 1.0^{\circ} \mathrm{C}( \pm 1.80 \mathrm{~F})$ of the desired test values at all times during the tests. Its heating and cooling capacity shall be selected so that dry bulb temperature of the air entering the reconditioning apparatus may be raised or lowered the required amount to meet the applicable test conditions in Section 8.

\section{SECTION 8. TEST PROCEDURE AND CALCULATIONS}

\subsection{GENERAL}

The performance of the solar collector is determined by obtaining values of instantaneous efficiency for a large combination of values of incident insolation, ambient temperature, and inlet fluid temperature. This requires experimentally measuring the rate of incident solar radiation onto the solar collector as well as the rate of energy addition to the transfer fluid as it passes through the collector, all under quasi-steady conditions.

\subsection{INSTANTANEOUS EFFICIENCY}

It has been shown and discussed by a number of investigators [17, 18,19 and 20] that the performance of flat plate solar collector operating under steady conditions can be successfully described by the following relationship:

$*$

Usually an orifice, venturi, or flow nozzle.

$* *$

For small flow elements, the discharge coefficients associated with elements varies considerably from those associated with the larger elements. In addition, for small pipe or duct sizes, the ratio of pipe circumference to pipe area becomes large and the characteristics of the upstream and downstream pipe sections affect the behavior of the element itself. 


$$
\frac{q_{u}}{A}=I(\tau \alpha)_{e}-U_{L}\left(t_{p}-t_{a}\right)
$$

A very similar equation can be used to describe the performance of concentrating collectors [21,22 and 23]. Equation (1) becomes modified as follows [21]:

$$
\frac{\mathrm{q}_{\mathrm{u}}}{\mathrm{A}_{\mathrm{a}}}=\mathrm{I}(\tau \alpha)_{e} \rho \gamma-\mathrm{U}_{\mathrm{L}} \frac{\mathrm{A}_{\mathrm{r}}}{\mathrm{A}_{\mathrm{a}}}\left(\mathrm{t}_{\mathrm{r}}-\mathrm{t}_{\mathrm{a}}\right)
$$

To assist in obtaining detailed information about the performance of collectors and to prevent the necessity of determining some average surface temperature, it has been convenient to introduce a parameter $\mathrm{F}^{\prime}$ where

$$
\begin{aligned}
& \mathrm{F}^{\prime} \equiv \frac{\text { actual useful energy collected }}{\text { useful energy collected if the }} \\
& \text { entire collector surface were } \\
& \text { at the average fluid tempera- } \\
& \text { ture }
\end{aligned}
$$

Introducing this factor into equation (1) results in

$$
\frac{\mathrm{q}_{\mathrm{u}}}{\mathrm{A}}=\mathrm{F}^{\prime}\left[\mathrm{I}(\tau \alpha)_{e}-\mathrm{U}_{\mathrm{L}}\left(\frac{\mathrm{t}_{\mathrm{f}, \mathrm{i}}+\mathrm{t}_{\mathrm{f}, \mathrm{e}}}{2}-\mathrm{t}_{\mathrm{a}}\right)\right]
$$

If the solar collector efficiency can be defined as

$$
\begin{aligned}
& \eta \equiv \frac{\text { actual useful energy collected }}{\text { solar energy incident upon or }} \\
& \text { intercepted by the collector }
\end{aligned}
$$

or in equation form

$$
\eta=\frac{\mathrm{q}_{\mathrm{u}} / \mathrm{A}}{\mathrm{I}}
$$

then the efficiency of the flat-plate collector is given by: 


$$
\eta=F^{\prime}(\tau \alpha) e^{-F^{\prime} U_{L} \frac{\left(\frac{t_{f, i}+t_{f, e}}{2}-t_{a}\right.}{I}}
$$

Equation (5) indicates that if the efficiency is plotted against an appropriate $\frac{\Delta t}{I}$, a straight line will result where the slope is some function of ${ }^{1} \mathrm{U}_{\mathrm{L}}$ and the $\mathrm{y}$ intercept is some function of $(\tau \alpha)_{\mathrm{e}}$. In reality $U_{L}$ is not a constant but rather a function of the temperature of the collector and of the ambient weather conditions. In addition, the product $(\tau \alpha)_{e}$ varies with incident angle to the collector.

The procedures outlined in this document have been developed in an attempt to control the test conditions so that a well defined efficiency "curve" can be obtained with a minimum of scatter. Figure A7 shows typical test results taken from reference [24] for two flat-plate collectors using air as the transfer fluid. The collector tests were conducted outside and the scatter about the two lines in each figure indicates "... apart from experimental errors, the order of variation on account of the variations in heat loss coefficient $U_{L}$, and the parameter $F^{\prime}$ due to variations in ambient wind speed and sky temperatures". Figure A10 was taken from reference [25] and is for a flat-plate collector using water as the transfer fluid. There is less scatter due to the fact that the tests were conducted indoors using a "solar simulator"l.

The curves shown in Figures $\mathrm{A} 7$ and $\mathrm{A} 10$ are duplicates of those reported in references [24] and [25], respectively. The abscissa in the first. case is in metric units and in the second, english units. The curves to be presented in the test report described herein should be done so the abscissa is either in the SI units of $\left(\mathrm{C}^{2} \cdot \mathrm{m}^{2}\right) / \mathrm{W}$ (as in Figures $\mathrm{A} 8$ and $\mathrm{A} 11$ ) or as shown in Figures $\mathrm{A} 9$ and $\mathrm{A} 12$. Here the experimentally determined temperature difference has been divided by the difference in temperature between the boiling point and freezing point on the respective scale $\left(100^{\circ} \mathrm{C}, 180^{\circ} \mathrm{F}\right)$ and the insolation has been divided by the solar constant, $\mathrm{I}_{\mathrm{SC}}\left(1353 \mathrm{~W} / \mathrm{m}^{2}\right)$, in appropriate units [26]. The result is an abscissa whose units are dimensionless.

It is expected that a "straight-line" representation will suffice for most conventional flat-plate collectors but that an attempt to represent the performance of a concentrating collector on such a plot will require the use of a "higher-order fit" due to the larger variation in $\mathrm{U}_{\mathrm{L}}$ and the product $(\tau \alpha) \mathrm{e}^{\circ}$ 
The testing of the solar collector shall be conducted in such a way that an "efficiency curve" is determined for the collector under test conditions described in Section 5. and 8.3. At least four different values of inlet fluid temperature shall be used to obtain the values of $\Delta t / I$. Ideally the inlet fluid temperature should correspond to $10,30,50$, and $70^{\circ} \mathrm{C}\left(18,54,90\right.$, and $\left.126^{\circ} \mathrm{F}\right)$ above the ambient temperature; however the values that can realistically be used will depend upon the particular collector design and the environmental conditions at the location and time of year when the collector is being tested. Consequently, the four different inlet fluid temperatures selected should be as close to the above values as is feasible. At least four "data points" shall be taken for each value of $t_{f, i}$; two during the time period preceding solar noon and two in the period following solar noon, the specific periods being chosen so that the data points represent times symmetrical to solar noon. This latter requirement is made so that any "transient effects" that may be present will not bias the test results when they are used for design purposes. All test data shall be reported in addition to the fitted curve (see Section 9.) so that any difference in efficiency due solely to the operating temperature level of the collector can be discerned in the test report. The curve shall be established by "data points" that represent 15 minute integrated efficiency values. In other words, the integrated value of incident solar energy will be divided into the integrated value of energy obtained from the collector to obtain the efficiency value for that "instant". Care should be taken to insure that the incident solar energy is steady for each 15 minute segment during which an efficiency value is calculated. Either electronic integrators or continuous pen strip chart recorders may be used to determine the integrated values of incident solar radiation and temperature rise across the collector. However, a strip chart recorder with a recommended chart speed of $30 \mathrm{~cm} / \mathrm{hr}$ must always be used to monitor the output of the pyranometer to insure that the incident radiation has remained steady during the 15 minute segment. Figures $\mathrm{A} 13$ and $\mathrm{A} 14$ show a strip chart recording of incident solar radiation on a horizontal surface at the National Bureau of Standards site in Gaithersburg, Maryland. Whereas the conditions of Figure A13 would be perfectly acceptable for obtaining efficiency values, those of Figure $\mathrm{Al} 4$ would not be*.

One or two "blips" of $10 \mathrm{~s}$ or less occurring during the 15 minute period such as at $12: 18$ in Figure All is acceptable. 
The surface of the collector cover plate (if present) as well as exposed envelope of the pyranometer should be wiped clean and dry prior to the tests. If local pollution or sand has formed a deposit on the transparent surfaces, the wiping should be carried out very gently, preferably after blowing off most of the loose material or after wetting it a little, in order to prevent scratching of the surface. This is particularly important for the pyranometer since such abrasive action can appreciably alter the original transmission properties of the enclosing envelope.

The pyranometer shall be checked prior to testing to see if there is any accumulation of water vapor enclosed within the glass cover. The use of "wet" pyranometers (where moisture is visible) shall not be allowed.

In order to obtain sufficiently good "quasi-steady" conditions for the solar collection process, the collector should stand in the sun under no flow conditions until the contained fluid heats up to a temperature equivalent to or slightly greater than the inlet fluid temperature for the test. The transfer fluid should then be circulated through the collector at the appropriate temperature level for at least 30 minutes* $^{*}$ prior to the period in which data will be taken to calculate the efficiency values. During this period, a check should be made to insure that the flow rate of the transfer fluid does not vary by more than $\pm 1 \%$ and that the incident solar radiation is steady as described above.

The flow rate of transfer fluid through the collector shall be standardized at one value for all data points. The recommended value of flow rate per unit area (transparent frontal or aperture) for tests are $0.02 \mathrm{~kg} /\left(\mathrm{s} \cdot \mathrm{m}^{2}\right)\left(14.7 \mathrm{lbm} /\left(\mathrm{h} \cdot \mathrm{ft}^{2}\right)\right)$ when a 1iquid is the transfer fluid and $0.01 \mathrm{~m}^{3} /\left(\mathrm{s} \cdot \mathrm{m}^{2}\right)\left(1.96 \mathrm{cfm}\right.$ per $\left.\mathrm{ft}^{2}\right)$ of standard are when the transfer fluid is air. It is recognized that in some cases the collector will have been designed for a flow rate much different than specified above. In such cases, the design flow rate should be used.

In order to determine and report the fraction of the incident solar radiation that is diffuse for each efficiency value, the sensing element of the pyranometer shall be shaded from the direct beam of sun just prior and just following each 15 minute testing

30 minutes is felt to be sufficient for typical tube and sheet type solar collectors using water as the transfer fluid. For those collectors having higher thermal capacity, a longer time period may be necessary. 
period and the value of the incident radiation determined*. This shall be accomplished by using a small disk attached to a slender rod held on a direct line between the pyranometer and the sun. The disk should be just large enough to shade the sensing element alone. In reference [5], this is accomplished by a disk $100 \mathrm{~mm}$ in diameter and held at a distance of $1 \mathrm{~m}$ from the sensing element $* *$.

\subsection{CALCULATION OF INSTANTANEOUS EFFICIENCY}

For each 15 minute segment for which an efficiency value is to be determined, the value is calculated using the equation:

$$
\eta=\frac{\Gamma \dot{\mathrm{m}} \mathrm{c}_{\mathrm{p}} \int_{\tau_{1}}^{\tau_{2}}\left(\mathrm{t}_{\mathrm{f}, \mathrm{e}}-\mathrm{t}_{\mathrm{f}, \dot{\mathrm{i}}}\right) \mathrm{d} \tau \cdot / \mathrm{A}_{\mathrm{a}}}{\int_{\tau_{1}}^{\tau_{2}} \mathrm{I} \mathrm{d} \tau}
$$

The quantities $\dot{m}$ and $c_{p}$ have been taken out of the integration in the numerator since they remain essentially constant during the test. Note that the collector area used for the calculation is not the absorbing surface area but rather the transparent frontal area or aperture area.

At least sixteen data points shall be obtained for the establishment of the "efficiency curve" and an equation for the curve shall be obtained using the standard technique of a least-squares fit to a second-order polynomial***.

\subsection{AN EXPERIMENTAL CHECK}

As an independent check on the experimental results, the inlet temperature, $t_{f, i}$, and the out let temperature, $t_{f, e}$, of the collector shall be recorded on continuous pen strip chart recorders. The

A normal incidence pyrheliometer can be used in lieu of shading the sensing element of the pyranometer.

$x+$

This was when using a Moll-Gorszynski Pyranometer made by Kipp and Zonen.

$* * *$

One should consult any standard text discussing analysis of experimental data for a presentation of this technique (i.e., [27] and [28]). 
quantity $\int_{T}^{T_{1}}\left(t_{\mathrm{f}, e}-t_{\mathrm{f}, \mathrm{i}}\right) \mathrm{d} T$ shall be approximated using these recordings and compared with the identical quantity obtained by using the primary method which measures the temperature difference directly.

\subsection{CALCULATION OF AIR FLOW RATE}

The air flow rate through the nozzle is calculated by the following equations:

$$
\begin{aligned}
& \mathrm{Q}_{\mathrm{mi}}=1.41 \mathrm{CA}_{\mathrm{n}}\left(\mathrm{P}_{\mathrm{v}} \mathrm{v}_{\mathrm{n}}^{\prime}\right)^{0.5} \\
& \mathrm{v}_{\mathrm{n}}^{\prime}=10.1 \times 10^{4} \mathrm{v}_{\mathrm{n}} / \mathrm{P}_{\mathrm{n}}\left(1+\mathrm{w}_{\mathrm{n}}\right)
\end{aligned}
$$

The air flow rate of standard air is then:

$$
Q_{\mathrm{s}}=Q_{\mathrm{mi}} /\left(1.2 \mathrm{v}_{\mathrm{n}}^{\prime}\right)
$$

\subsection{CALCULATION OF NOZZLE REYNOLDS NUMBER}

The Reynolds number is calculated as follows:

$$
\mathrm{N}_{\mathrm{Re}}=\mathrm{f} \mathrm{V}_{\mathrm{a}} \mathrm{D}
$$

The temperature factor is as follows:

$$
\text { Temperature, }{ }^{\circ} \mathrm{C}
$$

$$
-6.7
$$$$
+4.4
$$$$
+15.6
$$$$
+26.7
$$$$
+37.8
$$$$
+48.9
$$$$
+60.0
$$$$
+71.1
$$

Factor, f

48825 
8.8 CALCULATION OF THEORETICAL POWER REQUIREMENTS

In order to calculate the theoretical power required to move the transfer fluid through the solar collector, the following equation shall be used:

$$
\mathrm{P}_{\text {th }}=\dot{\mathrm{m}} \Delta \mathrm{P} / \rho
$$


9.1 TEST DATA

Table A13 lists the measurements which are to be made at the beginning of the testing day and during the individual tests to obtain an efficiency "data point".

\subsection{TEST REPORT}

Table Al4 specifies the data and information that shall be reported in testing the solar collector.

\section{SECTION 10. NOMENCLATURE}

A

A

$\mathrm{A}_{\mathrm{n}}$

A

C

$c_{p}$

D

f

$F^{\prime}$

h

I

$I_{d}$

$I_{S C}$ cross-sectional area, $\mathrm{m}^{2}$

transparent frontal area for a flat-plate collector or aperture for a concentrating collector, $\mathrm{m}^{2}$

area of nozzle, $\mathrm{m}^{2}$ absorbing or receiving area of the concentrating solar collec-
tor, $\mathrm{m}^{2}$

nozzle coefficient of discharge

specific heat of the transfer fluid, J/(kg.OC)

nozzle throat diameter, m

temperature factor for the calculation of nozzle $\mathrm{N}_{\mathrm{Re}}$

solar collector efficiency factor

outside surface heat transfer coefficient (includes radiation and convection) for the solar collector, $\mathrm{W} /\left(\mathrm{m}^{2} .{ }^{\circ} \mathrm{C}\right)$

total solar energy incident upon the plane of the solar collector per unit time per unit area, $\mathrm{W} / \mathrm{m}^{2}$

diffuse solar energy incident upon the plane of the solar collector per unit time per unit area, $\mathrm{W} / \mathrm{m}^{2}$

solar constant, $1353 \mathrm{~W} / \mathrm{m}^{2}$ 
mass flow rate of the transfer fluid, $\mathrm{kg} / \mathrm{s}$

Reynolds number

absolute pressure at the nozzle throat, $\mathrm{N} / \mathrm{m}^{2}$

theoretical power required to move the transfer fluid through the solar collector, W

velocity pressure at the nozzle throat or the static pressure difference across the nozzle, $\mathrm{N} / \mathrm{m}^{2}$ pressure drop across the solar collector, $\mathrm{N} / \mathrm{m}^{2}$

measured air flow rate, $\mathrm{m}^{3} / \mathrm{s}$

standard air flow rate, $\mathrm{m}^{3} / \mathrm{s}$

rate of useful energy extraction from the solar collector, W

ambient air temperature, ${ }^{\circ} \mathrm{C}$

temperature of the boiling point on a temperature scale, ${ }^{\circ} \mathrm{C}$ or ${ }^{\circ} \mathrm{F}$ temperature of the fluid leaving the collector, ${ }^{\circ} \mathrm{C}$ temperature of the fluid entering the collector, ${ }^{\circ} \mathrm{C}$ temperature of freezing point on a temperature scale, ${ }^{\circ} \mathrm{C}$ or ${ }^{\circ} \mathrm{F}$ average temperature of the absorber surface of the solar collector, ${ }^{\circ} \mathrm{C}$

average temperature of the absorber surface of the concentrating solar collector, ${ }^{\circ} \mathrm{C}$

temperature difference, ${ }^{\circ} \mathrm{C}$

heat transfer loss coefficient for the solar collector, $\mathrm{W} / \mathrm{m}^{2} \cdot{ }^{\mathrm{O}} \mathrm{C}$ ) velocity of the air at the nozzle throat, $\mathrm{m} / \mathrm{s}$

specific volume of the air at dry and wet bulb temperature conditions existing at the nozzle but at standard barometric pressure, $\mathrm{m}^{3} / \mathrm{kg}$ dry air

specific volume of the air at the nozzle, $\mathrm{m}^{3} / \mathrm{kg}$ dry air humidity ratio at the nozzle, $\mathrm{kg} \mathrm{H}_{2} 0 / \mathrm{kg}$ dry air absorptance of the solar collector absorbing surface to solar radiation which is intercepted by the solar collector absorbing surface 
solar collector efficiency, \%

specular reflectance of the solar collector reflector, or density, $\mathrm{kg} / \mathrm{m}^{3}$ time, s, or transmittance of the solar collector cover plate

$(\tau \alpha)_{e}$ effective transmission-absorptance factor for the solar collector time at the beginning of a 15 minute test period, $\mathrm{s}$

$\tau_{2}$ time at the end of a 15 minute test period, s

\section{SECTION 11. REFERENCES}

1. Morrison, C. A., and E. A. Farber, "Development and Use of Insolation Data for South Facing Surfaces in Northern Latitudes", paper presented at the ASHRAE Symposium, Solar Energy Applications, Montreal, Canada, June 22,1974 .

2. Personal communication with J. I. Yellott, Arizona State University, Tempe, Arizona, data to be published in 1975 revised edition of the ASHRAE publication, Low Temperature Engineering Application of Solar Energy.

3. ASHRAE Handbook of Fundamentals, American Society of Heating, Refrigerating and Air-Conditioning Engineers, Inc., 345 East 47 th Street, New York, N. Y. 10017, 1972 .

4. Threlkeld, J. L., Therma 1 Environmental Engineering, Prentice-Hall, Englewood Cliffs, New Jersey, Second Edition, 1970.

5. Latimer, J. R., "Radiation Measurement", International Field Year for the Great Lakes, Technical Manual Series, No. 2, The Secretariet, Canadian National Committee for the International Hydrological Decade, No. 8 Building, Carling Avenue, Ottawa, Canada, 1971.

6. "Standard Measurements Guide: Section on Temperature Measurements", ASHRAE Standard 41-66, Part 1, American Society of Heating, Refrigerating and Air-Conditioning Engineers, Inc., 345 East 47 th Street, New York, N. Y. 10017, January, 1966.

7. "American Standard for Temperature Measurement Thermocouples C96.11964" (R 1969), American National Standards Institute, 1969.

8. "Instruments and Apparatus, Part 3, Temperature Measurement", Supplement to the ASME Power Test Codes, American Society of Mechanical Engineers, 345 East 47th Street, New York, N. Y. 10017, March, 1961. 
9. Davis, J. C., "Radiation Errors in Air Ducts Under Isothermal Conditions Using Thermocouples, Thermistors, and a Resistance Thermometer", NBS_Building Science Series 26, November, 1969. (Available from the Superintendent of Documents, U. S. Government Printing Office, Washington, D. C. 20402 - order by SD Catalog No. C 13.29/2:26, $\$ 0.25$.

1). Davis, J. C., Faison, T. K., and P. R. Achenbach, "Errors in Temperature Measurement of Moving Air Under Isothermal Conditions Using Thermocouples, Thermistors, and Thermometers, ASHRAE Transactions, Vol. 72, Part 1, 1966.

1). "Methods of Testing for Rating Unitary Air Conditioning and Heat Pump Equipment", ASHRAE Standard 37-69, American Society of Heating, Refrigerating and Air-Conditioning Engineers, Inc., 345 East 47th Street, New York, N. Y. 10017, April, 1969.

12. "Instruments and Apparatus, Part 2, Pressure Measurement", Supplement to the ASME Power Test Codes, American Society of Mechanical Engineers, 345 East 47th Street, New York, N. Y. 10017, July, 1964.

13. "Instruments and Apparatus, Part 5, Measurement of Quantity of Materials, Chapter 4, Flow Measurement", Supplement to the ASME Power Test Codes, American Society of Mechanical Engineers, 345 East 47 th Street, New York, N. Y. 10017, February, 1959.

14. "Fluid Meters, Their Theory and Application", 5th edition, American Society of Mechanical Engineers, 345 East 47th Street, New York, N. Y. $10017,1959$.

15. "Instructions for Climatological Observations, Circular B", United States Weather Bureau Service, 11th edition, January, 1962.

16. Faison, T. K., Davis, J. C., and P. R. Achenbach, "Performance of Louvered Devices as Air Mixers, NBS Building Science Series 27 , March, 1970. (Available from the Superintendent of Documents, U. S. Government Printing Office, Washington, D. C. 20402 - order by SD Catalog No. C $13.29 / 2: 27, \$ 0.30$. )

17. Hottel, H. C., and B. B. Woertz, "The Performance of Flat-Plate Solar-Heat Collectors", ASME Transactions, Vo1. 64, p. 91, 1942.

18. Hottel, H. C., and A. Whillier, "Evaluation of Flat-Plate Collector Performance", Transactions of the Conference on the Use of Solar Energy, Vol. 2, Part I, p. 74, University of Arizona Press, 1958 .

19. Bliss, R. W., "The Derivation of Several 'Plate-Efficiency Factors' Useful in the Design of Flat-Plate Solar Heat Collectors", Solar Energy, Vol. 3, No. 4, p. 55, 1959. 
20. Whillier, A., "Design Factors Influencing Collector Performance", Low Temperature Engineering Application of Solar Energy, American Society of Heating, Refrigerating and Air-Conditioning Engineers, Inc., 345 East 47th Street, New York, N. Y. 10017, 1967.

21. Duffie, J. A., and W. A. Beckman, Solar Energy Thermal Processes, John Wiley and Sons, 1974.

22. Nevins, R. G., and P. E. McNa11, "A High-Flux Low-Temperature Solar Collector", ASHRAE Transactions, Vol. 64, pp. 69-82, 1958.

23. Löf, G. O. G., Fester, D. A., and J. A. Duffie, "Energy Balance on a Parabolic Cylinder Solar Reflector", ASME Transactions, Vol. 84A, p. 24, 1962 .

24. Gupta, C. L., and H. P. Garg, "Performance Studies on Solar Air Heaters", Solar Energy, Vol. 11, No. 1, 1967.

25. Simon, F. F., and P. Harlament, "Flat-Plate Collector Performance Evaluation: The Case for a Solar Simulator Approach", NASA TM X71427, October, 1973 .

26. Thekaekara, M. P., "Solar Energy Outside the Earth's Atmosphere", Solar Energy, Vol. 14, No. 2, p. 109, 1973.

27. Holman, J. P., Experimental Methods for Engineers, McGraw-Hill, Second Edition, 1971.

28. Bevington, P.R., Data Reduction and Error Analysis for the Physica1 Sciences, McGraw-Hill, 1969. 


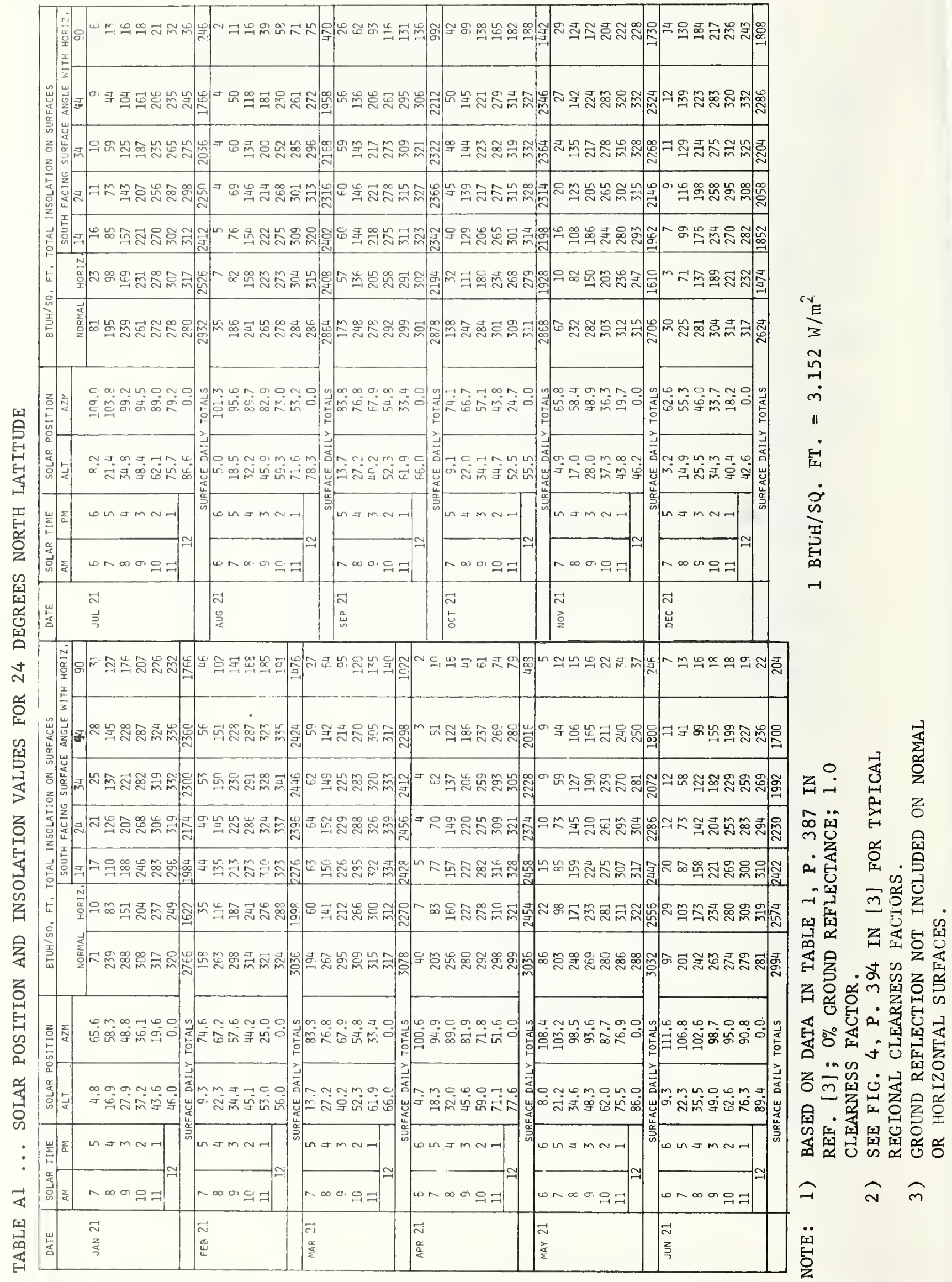


3.

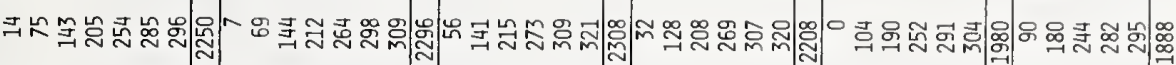

3 工

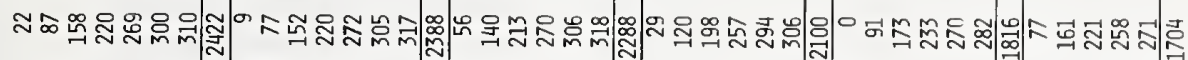

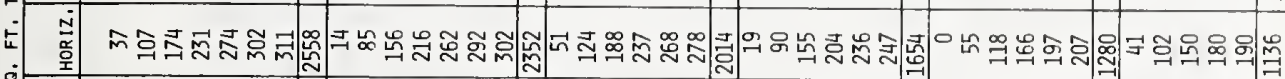

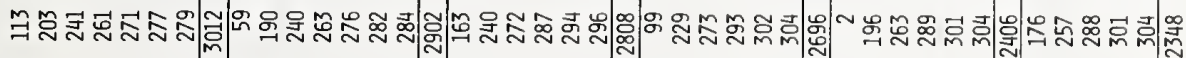
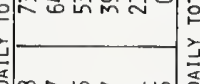

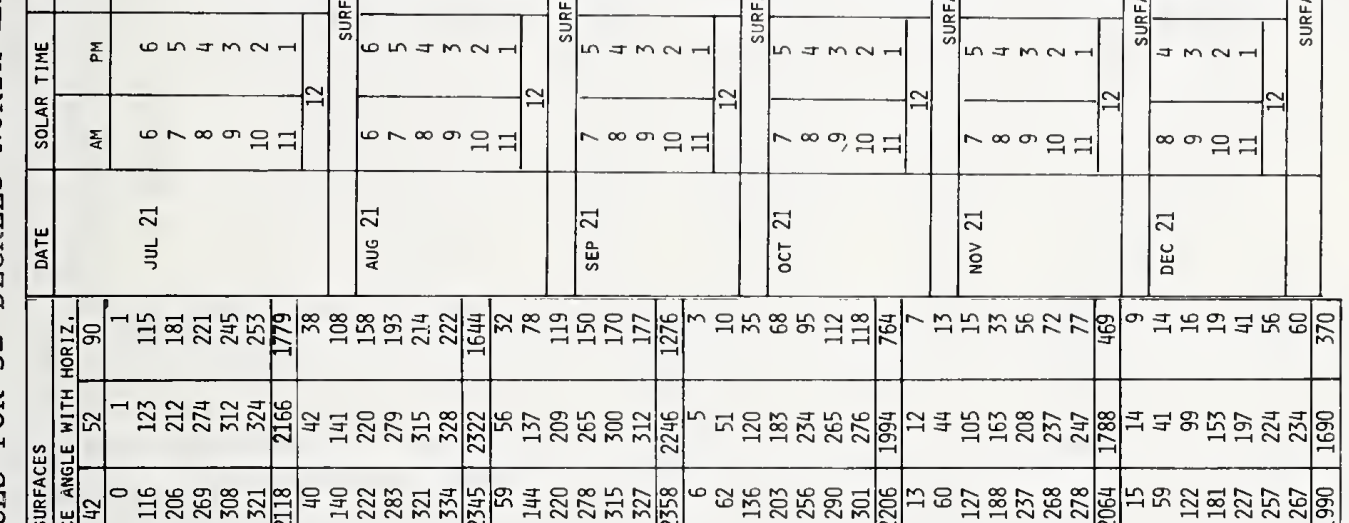

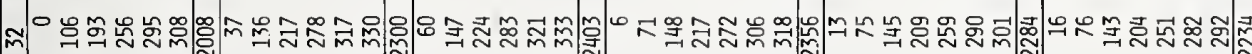
.

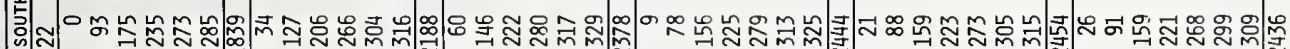

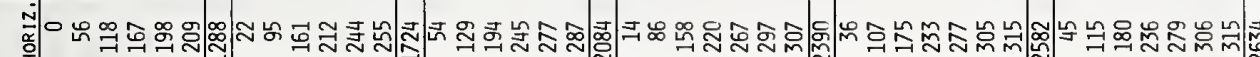

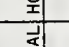

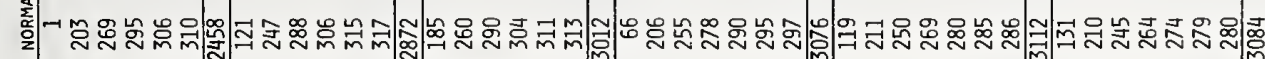

느은

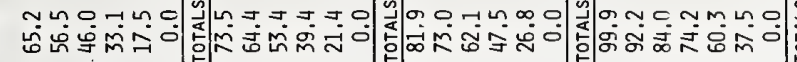

要

䑶
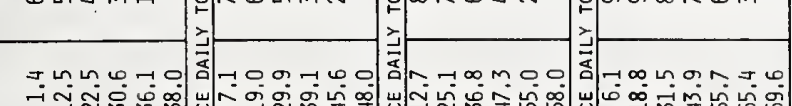

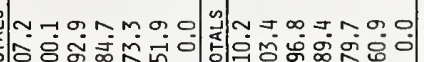

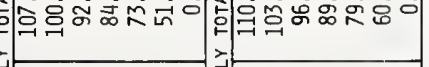

ᄂ 는
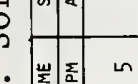

$\ln m \infty$
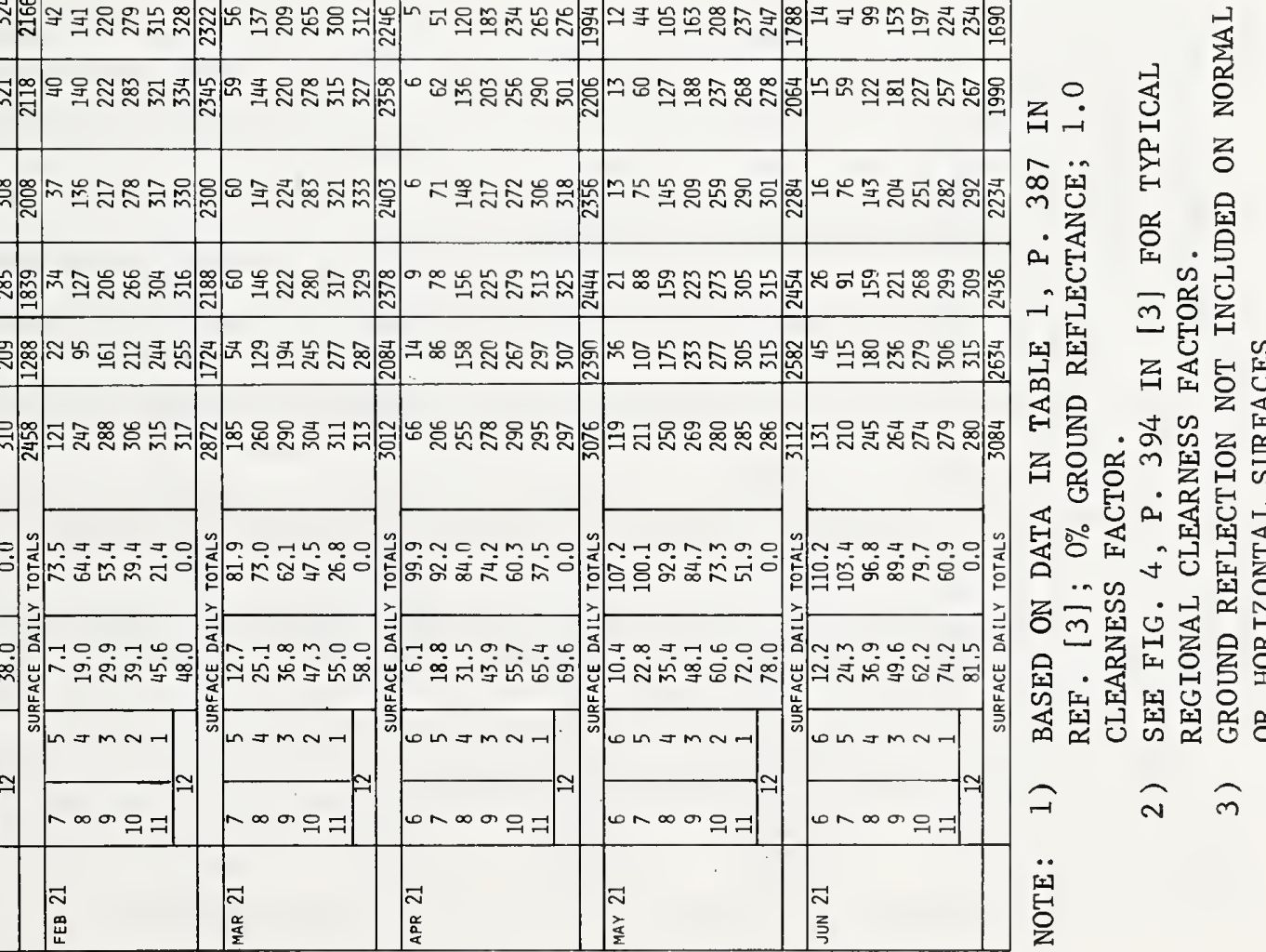

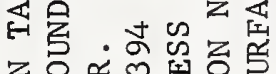

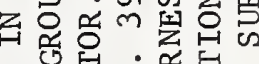

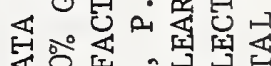

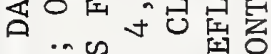

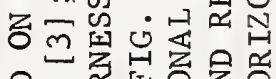
星. 总四各会虽

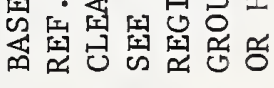
$\overparen{\sim} \widehat{m}$ 
施

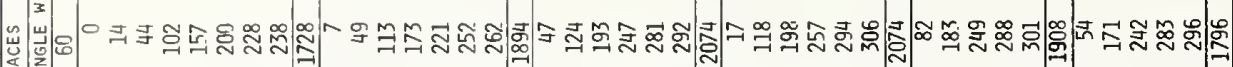

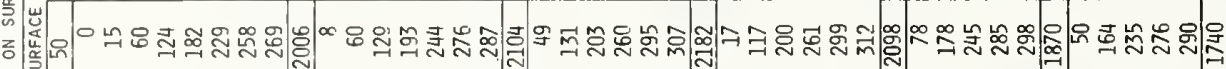

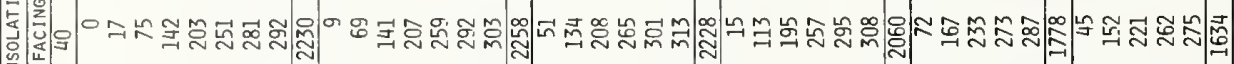
青施

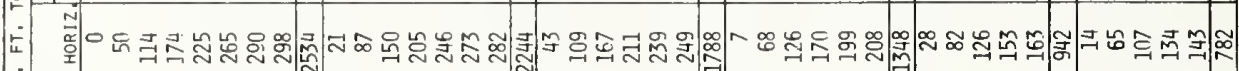
竞
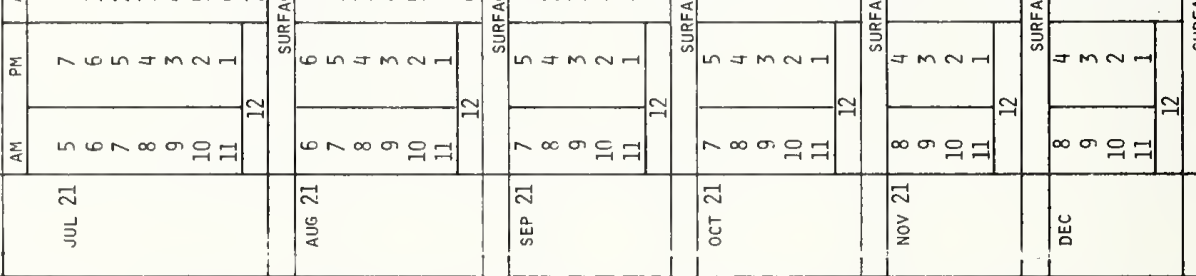

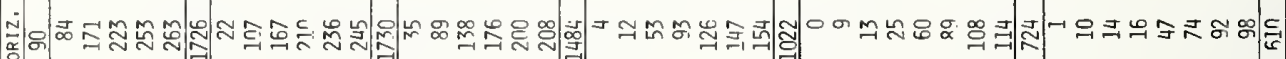

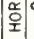
:

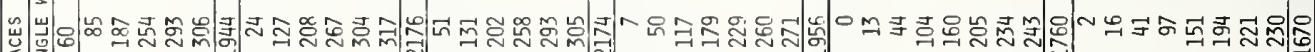
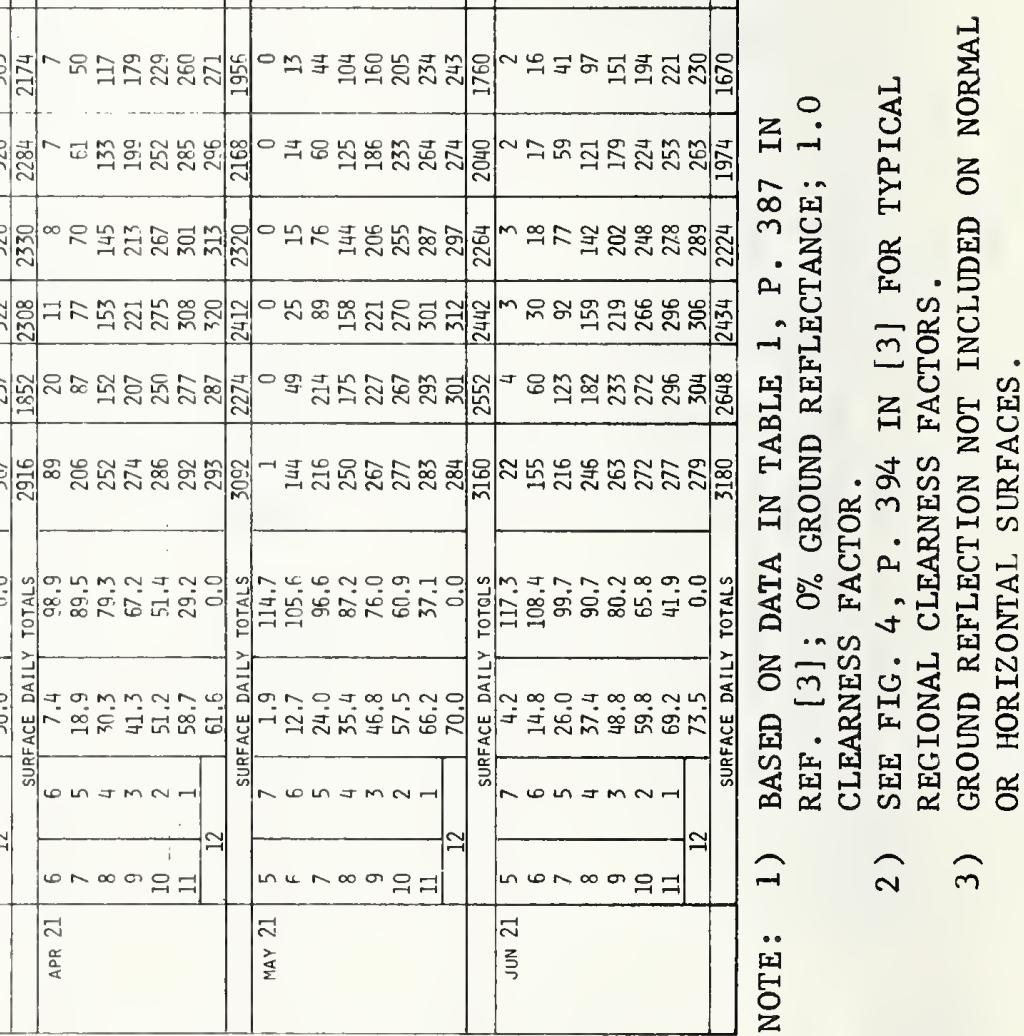


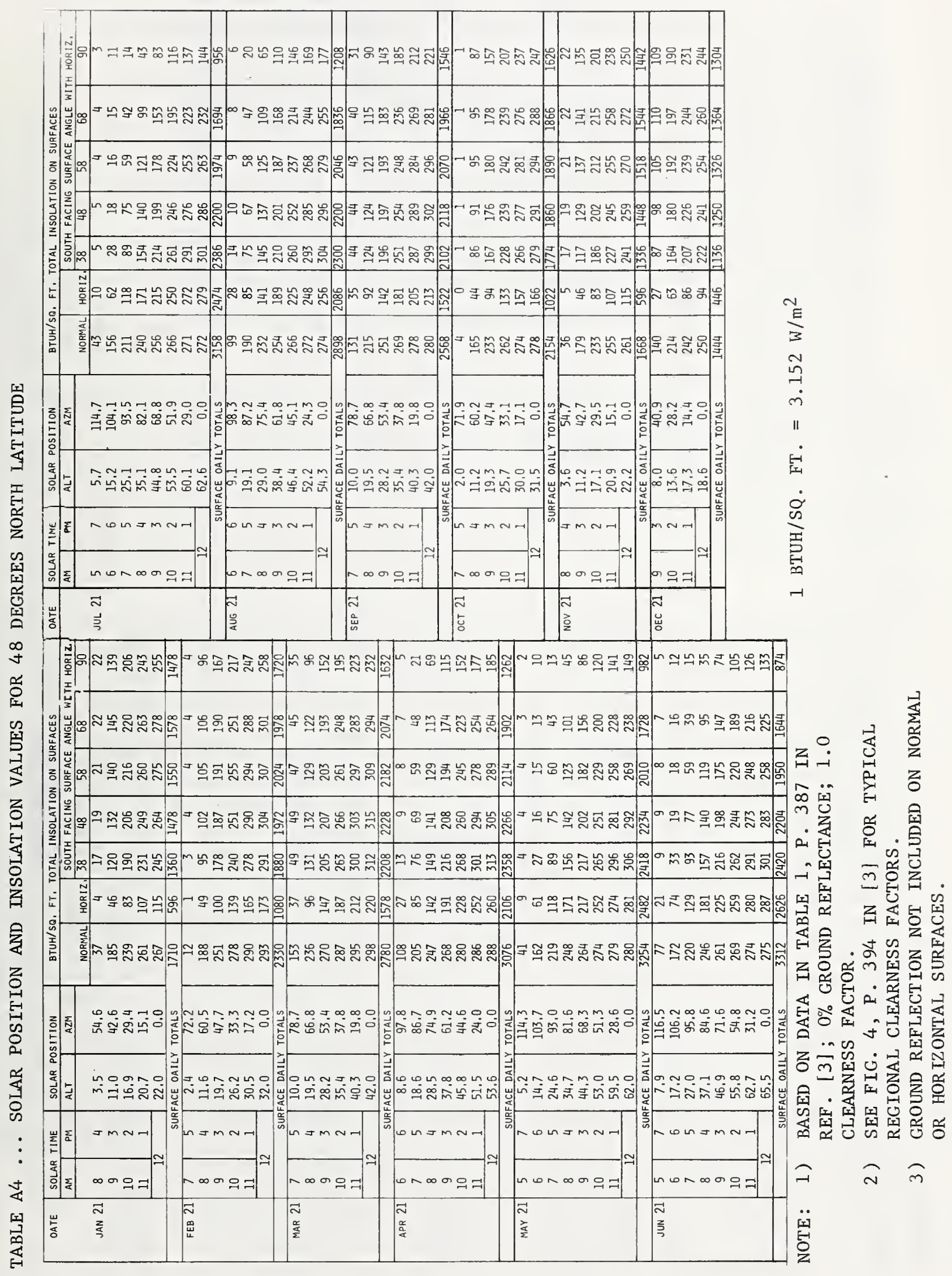




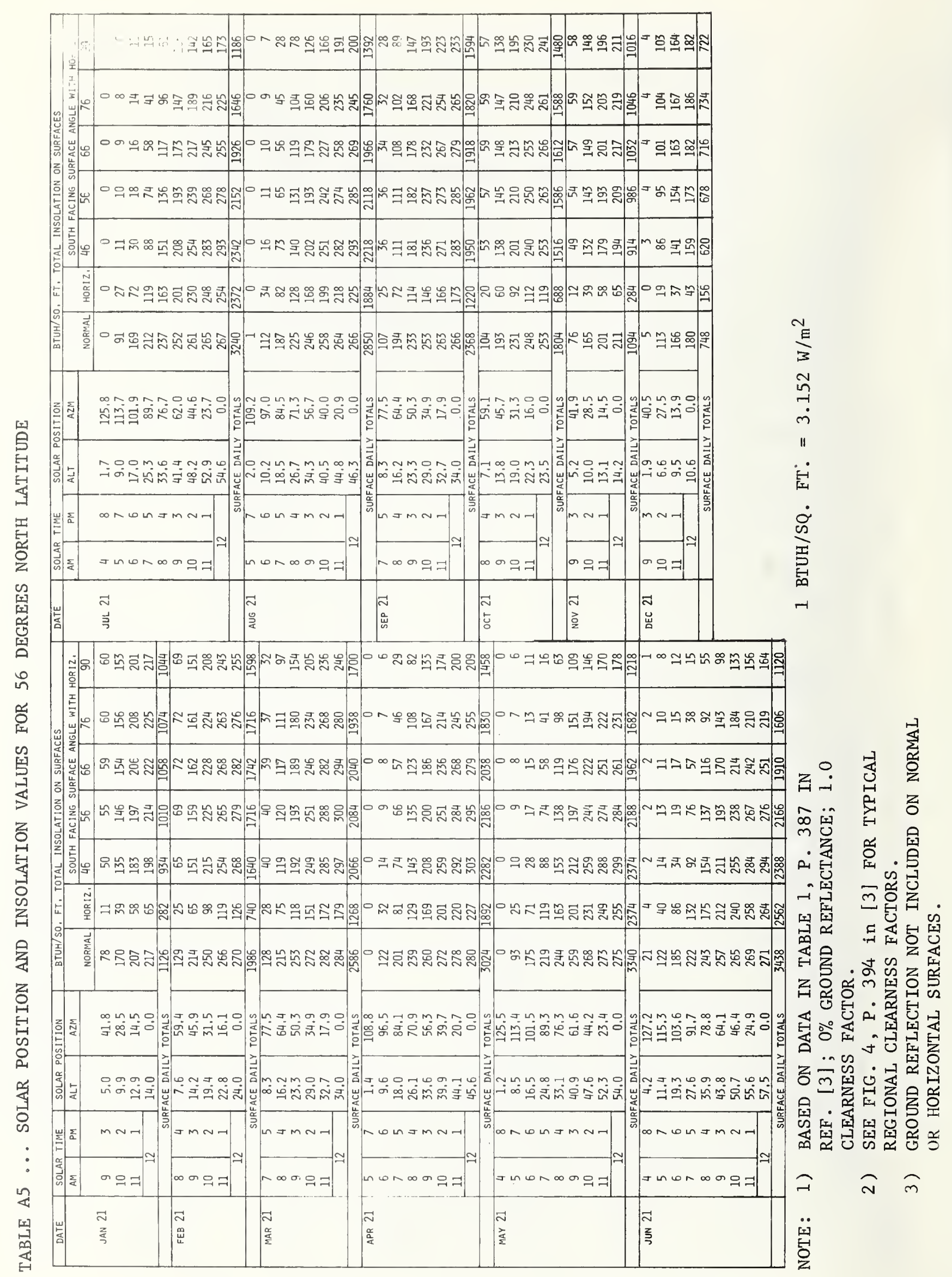




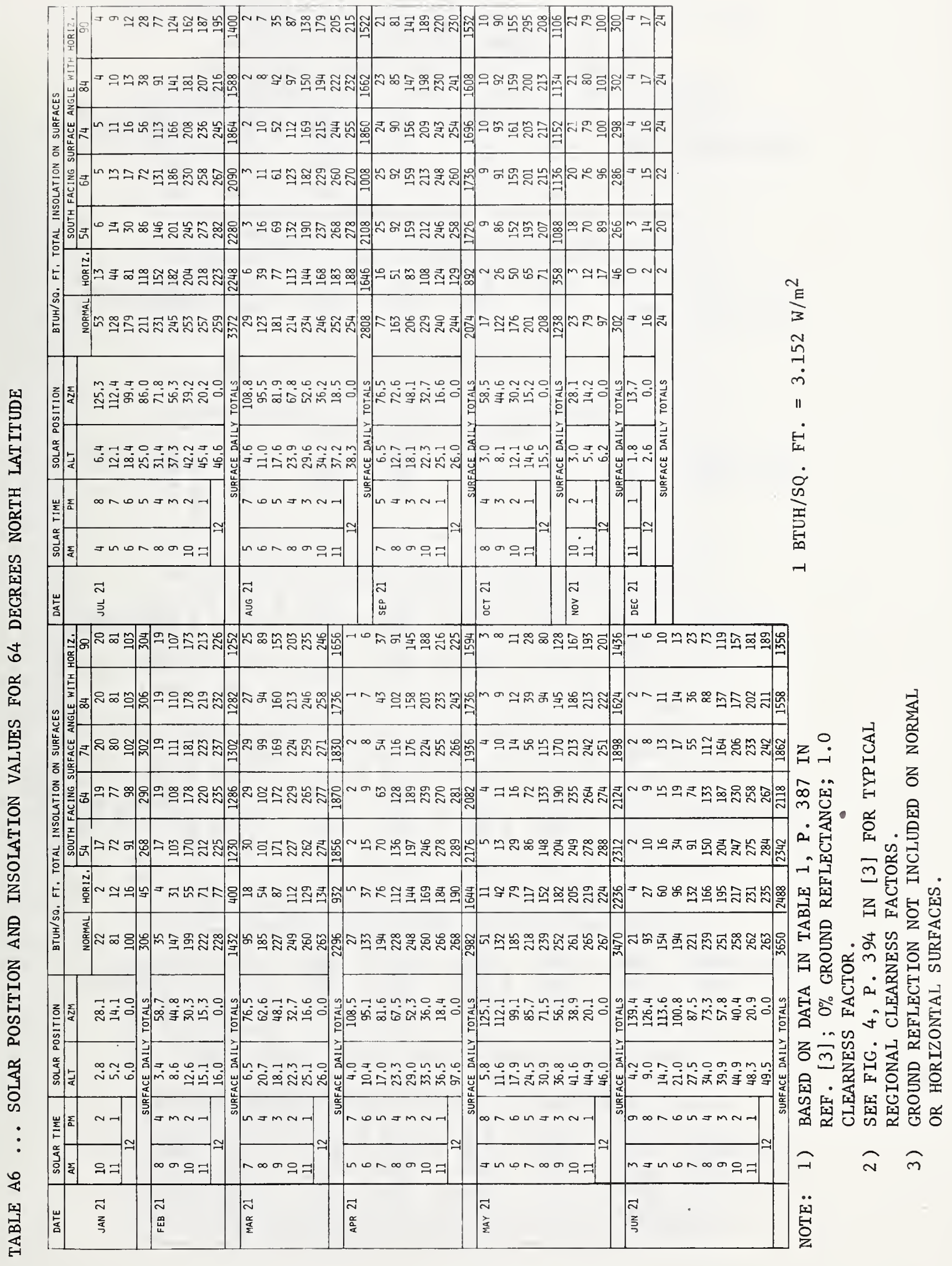


TABLE A7 LATITUDE $24^{\circ} \mathrm{N}$. INCIDENT ANGLES FOR HORIZONTAL AND SOUTH-FACING TILTED SURFACES

\begin{tabular}{|c|c|c|c|c|c|c|c|c|}
\hline & & & Moriz. & L-10 & Lat. & Lat. + 10 & Lat. + 20 & Vert. \\
\hline Dates: (Decl.) & 7 & 5 & 86.8 & 80.5 & 76.3 & 72.4 & 68.9 & 62.6 \\
Dec.2i (-23.45) & 8 & 4 & 75.1 & 67.5 & 62.7 & 58.6 & 55.4 & 56.6 \\
& 9 & 3 & 64.5 & 55.3 & 49.6 & 44.9 & 41.8 & 51.1 \\
& 11 & 1 & 55.7 & 44.5 & 37.4 & 31.6 & 28.0 & 46.6 \\
\hline & 12 & 49.6 & 36.5 & 27.6 & 19.6 & 14.3 & 43.6 \\
\hline
\end{tabular}

an. $21(-19.9)$

\begin{tabular}{|r|c|c|c|c|c|c|c|}
\hline & & Horiz. & L-10 & Lat. & Lat. + 10 & Lat. + 20 & Vert. \\
\hline 7 & 5 & 85.2 & 79.6 & 75.9 & 72.6 & 69.8 & 65.7 \\
8 & 4 & 73.3 & 66.2 & 62.0 & 58.5 & 56.0 & 59.8 \\
9 & 3 & 62.1 & 53.5 & 48.4 & 44.5 & 42.2 & 54.4 \\
10 & 2 & 52.8 & 42.1 & 35.5 & 30.6 & 28.2 & 50.0 \\
11 & 3 & 46.4 & 33.4 & 24.8 & 17.6 & 14.1 & 47.0 \\
\hline \multicolumn{2}{|c|}{12} & 44.0 & 30.0 & 20.0 & 10.0 & 0.0 & 46.0 \\
\hline
\end{tabular}

Feb. $21\{-10.6\}$

\begin{tabular}{|r|c|c|c|c|c|c|c|}
\hline & & Hortz. & L - 10 & Lat. & Lat. + 10 & L3t. + 20 & Vert. \\
\hline 7 & 5 & 80.7 & 77.2 & 75.2 & 73.7 & 72.6 & 74.8 \\
8 & 4 & 67.7 & 62.9 & 60.5 & 59.0 & 58.5 & 69.0 \\
9 & 3 & 55.6 & 49.0 & 45.9 & 44.3 & 44.5 & 63.8 \\
10 & 2 & 47.9 & 35.9 & 31.5 & 29.5 & 30.6 & 59.6 \\
\hline 11 & 1 & 37.0 & 25.0 & 18.0 & 14.8 & 17.6 & 56.9 \\
\hline & 12 & 34.0 & 20.0 & 10.0 & 0.0 & 10.0 & 56.0 \\
\hline
\end{tabular}

Sep. 21

\begin{tabular}{|r|c|c|c|c|c|c|c|}
\hline & & Horiz. & L - 10 & Lat. & Lat. + 10 & Lat. + 20 & Vert. \\
\hline 7 & & 76.3 & 75.2 & 75.0 & 75.2 & 75.9 & 84.0 \\
8 & 4 & 3.8 & 60.5 & 60.0 & 60.5 & 62.0 & 78.3 \\
9 & 3 & 49.8 & 45.9 & 45.0 & 45.9 & 48.4 & 73.3 \\
10 & 2 & 37.7 & 31.5 & 30.0 & 37.5 & 35.5 & 69.4 \\
\hline 11 & 1 & 28.1 & 18.0 & 15.0 & 18.0 & 24.8 & 66.9 \\
\hline 12 & 24.0 & 10.0 & 0.0 & 10.0 & 20.0 & 66.0 \\
\hline
\end{tabular}

\begin{tabular}{|r|r|c|c|c|c|c|c|}
\hline & Hor1z. & $L-10$ & Lat. & Lat. + 10 & Lat. + 20 & Vert. \\
\hline 6 & 6 & 85.3 & 88.0 & 90.0 & 92.0 & 93.9 & 100.6 \\
8 & 5 & 71.7 & 73.5 & 75.3 & 77.6 & 80.2 & 94.6 \\
9 & 4 & 58.0 & 58.9 & 60.7 & 63.4 & 67.0 & 89.1 \\
10 & 2 & 44.4 & 44.2 & 46.2 & 49.7 & 54.4 & 84.4 \\
11 & 3 & 31.0 & 29.5 & 32.0 & 36.8 & 43.2 & 80.7 \\
\hline \multicolumn{2}{|c|}{12} & 18.9 & 14.8 & 38.9 & 26.2 & 34.9 & 78.4 \\
\hline
\end{tabular}

Apr. 21
Aug. 21 $(+11.9)$

\begin{tabular}{r|c|c|c|c|c|c|c}
\hline & & Hor 12. & L-10 & Lat. & Lat. + 10 & Lat. + 20 & Vert. \\
\hline 6 & 6 & 82.0 & 86.0 & 90.0 & 93.4 & 96.7 & 108.2 \\
7 & 5 & 68.8 & 72.6 & 75.9 & 79.6 & 83.6 & 102.3 \\
9 & 4 & 55.4 & 58.5 & 62.0 & 66.2 & 71.1 & 97.0 \\
10 & 3 & 41.7 & 44.5 & 48.4 & 53.5 & 59.5 & 92.4 \\
11 & 2 & 28.0 & 30.6 & 35.5 & 42.1 & 49.6 & 88.9 \\
\hline \multicolumn{2}{|c|}{12} & 14.5 & 17.6 & 24.8 & 33.4 & 42.6 & 86.7 \\
\hline
\end{tabular}

May $21\left\{\begin{array}{l}+20.3 \\ \text { Ju1 } 21\end{array}\right\}$

\begin{tabular}{|r|c|c|c|c|c|c|c|}
\hline & & Hor1z. & L-10 & Lat. & Lat. + 10 & Lat. + 20 & Vert. \\
\hline 6 & 6 & 80.7 & 86.0 & 90.0 & 94.0 & 97.8 & 111.3 \\
7 & 5 & 67.7 & 72.4 & 76.3 & 80.5 & 85.0 & 105.5 \\
8 & 4 & 54.5 & 58.6 & 62.7 & 67.5 & 72.8 & 100.2 \\
9 & 3 & 41.0 & 44.9 & 49.6 & 55.8 & $6 ! .7$ & 95.7 \\
10 & 2 & 27.4 & 31.6 & 37.4 & 44.5 & 52.4 & 92.3 \\
11 & 1 & 13.7 & 19.7 & 27.6 & 36.5 & 45.9 & 90.2 \\
\hline \multicolumn{2}{|c|}{12} & 0.6 & 13.4 & 23.4 & 33.4 & 43.4 & 89.4 \\
\hline
\end{tabular}


TABLE A8 LATITUDE $32^{\circ} \mathrm{N}$. INCIDENT ANGLES FOR HORIZONTAL AND SOUTH-FACING TILTED SURFACES

\begin{tabular}{|c|c|c|c|c|c|c|c|c|}
\hline \multirow{3}{*}{$\begin{array}{l}\text { Dates (Decl.) } \\
\text { Dec. } 21(-23.45 \\
.\end{array}$} & & & Horiz. & $L-10$ & Lat. & Lat. +10 & Lat. +20 & Vert. \\
\hline & $\begin{array}{r}8 \\
9 \\
10 \\
11\end{array}$ & $\begin{array}{l}4 \\
3 \\
2 \\
1\end{array}$ & $\begin{array}{l}79.7 \\
70.2 \\
62.4 \\
57.3\end{array}$ & $\begin{array}{l}67.5 \\
55.3 \\
44.5 \\
36.5\end{array}$ & $\begin{array}{l}62.7 \\
49.6 \\
37.4 \\
27.6\end{array}$ & $\begin{array}{l}58.6 \\
44.9 \\
31.6 \\
19.6\end{array}$ & $\begin{array}{l}55.4 \\
41.8 \\
28.0 \\
14.3\end{array}$ & $\begin{array}{l}54.5 \\
47.1 \\
40.7 \\
36.2\end{array}$ \\
\hline & & & 55.4 & 33.4 & 23.4 & 13.5 & 3.5 & 34.5 \\
\hline
\end{tabular}

Jan. $21(-19.9)$

Nov. $21(-19.9)$

Feb. $21(-10.6)$

oct. $21(-10.7)$

Mar. $21(0.0)$

Sep. $21(0.0)$

Apr. $21(+11.9)$

Aug. $21(+12.1)$

May 21$\}+20.3\}$

Jul. $21(+20.5)$

Jun. $21(+23.45)$

\begin{tabular}{|r|l|c|c|c|c|c|c|}
\hline & & Hor1z. & L-10 & Lat. & Lat. +10 & Lat. + 20 & Vert. \\
\hline 7 & 5 & 88.6 & 79.6 & 75.9 & 72.6 & 69.8 & 65.2 \\
8 & 4 & 77.5 & 66.2 & 62.0 & 58.5 & 56.0 & 57.4 \\
9 & 3 & 67.5 & 53.5 & 48.4 & 44.5 & 42.2 & 50.0 \\
10 & 2 & 59.4 & 42.1 & 35.5 & 30.6 & 28.2 & 43.8 \\
11 & 1 & 53.9 & 33.4 & 24.8 & 17.6 & 14.1 & 39.6 \\
\hline \multicolumn{2}{|c|}{12} & 52.0 & 30.0 & 20.0 & 10.0 & 0.0 & 38.0 \\
\hline
\end{tabular}

\begin{tabular}{|r|c|c|c|c|c|c|c|}
\hline & & Horiz. & L -10 & Lat. & Lat. + 10 & Lat. + 20 & Vert. \\
\hline 8 & 5 & 82.9 & 77.2 & 75.2 & 73.7 & 72.6 & 73.6 \\
9 & 4 & 71.0 & 62.9 & 60.5 & 59.0 & 58.5 & 65.9 \\
10 & 2 & 60.1 & 49.0 & 45.9 & 44.3 & 44.5 & 58.9 \\
11 & 1 & 50.9 & 35.9 & 31.5 & 29.5 & 30.6 & 53.2 \\
\multicolumn{2}{|c|}{12} & 44.4 & 25.0 & 18.0 & 14.8 & 17.6 & 49.4 \\
& 42.0 & 20.0 & 10.0 & 0.0 & 10.0 & 48.0 \\
\hline
\end{tabular}

\begin{tabular}{|r|c|c|c|c|c|c|c|}
\hline & & Horiz. & $\mathrm{L}-10$ & Lat. & Lat. + 10 & Lat. + 20 & Vert. \\
\hline 7 & 5 & 77.3 & 75.2 & 75.0 & 75.2 & 75.9 & 82.1 \\
8 & 4 & 64.9 & 60.5 & 60.0 & 60.5 & 62.0 & 74.6 \\
9 & 3 & 53.2 & 45.9 & 45.0 & 45.9 & 48.4 & 68.0 \\
10 & 2 & 42.7 & 31.5 & 30.0 & 31.5 & 35.5 & 62.7 \\
11 & 1 & 35.0 & 18.0 & 15.0 & 18.0 & 24.8 & 59.2 \\
\hline \multicolumn{2}{|c|}{12} & 32.0 & 10.0 & 0.0 & 10.0 & 20.0 & 58.0 \\
\hline
\end{tabular}

\begin{tabular}{|r|c|c|c|c|c|c|c|}
\hline & & Horlz. & $\mathrm{L}-10$ & Lot. & Lat. + 10 & Lat. + 20 & Vert. \\
\hline 6 & 6 & 83.9 & 88.0 & 90.0 & 92.0 & 93.9 & 99.8 \\
7 & 5 & 71.2 & 73.5 & 75.3 & 77.6 & 80.2 & 92.1 \\
8 & 4 & 58.5 & 58.9 & 60.7 & 63.4 & 67.0 & 84.9 \\
9 & 3 & 46.1 & 44.2 & 46.2 & 49.7 & 54.4 & 78.7 \\
10 & 2 & 34.3 & 29.5 & 32.0 & 36.8 & 43.2 & .3 .8 \\
11 & 1 & 24.6 & 14.8 & 18.9 & 26.2 & 34.9 & 70.7 \\
\cline { 1 - 3 } & & 20.4 & 1.6 & 11.6 & 21.6 & 31.6 & 69.6 \\
\hline
\end{tabular}

\begin{tabular}{|c|c|c|c|c|c|c|c|}
\hline & & Horiz. & $L-10$ & tat. & Lat. +10 & Lat. +20 & vert. \\
\hline $\begin{array}{r}6 \\
7 \\
8 \\
9 \\
10 \\
11\end{array}$ & $\begin{array}{l}6 \\
5 \\
4 \\
3 \\
2 \\
1\end{array}$ & $\begin{array}{l}79.6 \\
67.2 \\
54.6 \\
41.9 \\
29.4 \\
18.0\end{array}$ & $\begin{array}{l}86.6 \\
72.6 \\
58.5 \\
44.5 \\
30.6 \\
17.6\end{array}$ & $\begin{array}{l}90.0 \\
75.9 \\
62.0 \\
48.4 \\
35.5 \\
24.8\end{array}$ & $\begin{array}{l}93.4 \\
79.6 \\
66.2 \\
53.5 \\
42.1 \\
33.4\end{array}$ & $\begin{array}{l}96.7 \\
83.6 \\
71.1 \\
59.5 \\
49.6 \\
42.6\end{array}$ & $\begin{array}{r}106.9 \\
99.3 \\
92.4 \\
86.4 \\
81.9 \\
79.0\end{array}$ \\
\hline \multicolumn{2}{|c|}{12} & 12.0 & 10.0 & 20.0 & 30.0 & 40.0 & 78.0 \\
\hline
\end{tabular}

\begin{tabular}{|c|c|c|c|c|c|c|c|}
\hline & & Horlz. & $L=10$ & tot. & Lat. +10 & Lat. +20 & Vert. \\
\hline $\begin{array}{r}6 \\
7 \\
8 \\
9 \\
10 \\
11\end{array}$ & $\begin{array}{l}6 \\
5 \\
4 \\
3 \\
2 \\
1\end{array}$ & $\begin{array}{l}77.8 \\
65.7 \\
53.1 \\
40.4 \\
27.8 \\
15.8\end{array}$ & $\begin{array}{l}86.0 \\
72.4 \\
58.6 \\
44.9 \\
31.6 \\
19.6\end{array}$ & $\begin{array}{l}90.0 \\
76.3 \\
62.7 \\
49.6 \\
37.4 \\
27.6\end{array}$ & $\begin{array}{l}94.0 \\
80.5 \\
67.5 \\
55.3 \\
44.5 \\
36.5\end{array}$ & $\begin{array}{l}97.8 \\
85.0 \\
72.8 \\
61.7 \\
52.4 \\
45.8\end{array}$ & $\begin{array}{r}109.7 \\
102.2 \\
95.4 \\
89.6 \\
85.2 \\
82.4\end{array}$ \\
\hline \multicolumn{2}{|c|}{12} & 8.6 & 13.4 & 23.4 & 33.4 & 43.4 & 81.4 \\
\hline
\end{tabular}


TABLE A9 LATITUDE $40^{\circ} \mathrm{N}$. INCIDENT ANGLES FOR HORIZONTAL AND SOUTH-FACING TILTED SURFACES

\begin{tabular}{|l|l|l|l|l|l|l|l|l|}
\hline & & & Horiz. & L-10 & Lat. & Lat. + 10 & Lat. + 20 & Vert. \\
\hline Date: (Dec1.) & 8 & 4 & 84.5 & 67.5 & 62.7 & 58.6 & 55.4 & 53.2 \\
Dec.21 (-23.45) & 9 & 3 & 76.0 & 55.3 & 49.6 & 44.9 & 41.8 & 43.8 \\
& 10 & 2 & 69.3 & 44.5 & 37.4 & 31.6 & 28.0 & 35.4 \\
\cline { 2 - 8 } & 11 & 65.0 & 36.5 & 27.6 & 19.6 & 14.3 & 29.0 \\
\hline \multicolumn{2}{|c|}{12} & 63.4 & 33.4 & 23.4 & 13.5 & 3.5 & 26.6 \\
\hline
\end{tabular}

\begin{tabular}{|c|c|c|c|c|c|c|c|c|}
\hline \multirow{3}{*}{ 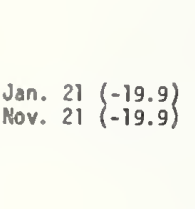 } & & & Horlz. & $L=10$ & Lat. & Lat. + 10 & Lat. + 20 & Vert. \\
\hline & $\begin{array}{r}8 \\
9 \\
10 \\
11\end{array}$ & $\begin{array}{l}4 \\
3 \\
2 \\
1\end{array}$ & $\begin{array}{l}81.9 \\
73.2 \\
66.2 \\
61.6\end{array}$ & $\begin{array}{l}66.2 \\
53.5 \\
42.7 \\
33.4\end{array}$ & $\begin{array}{l}62.0 \\
48.4 \\
35.5 \\
24.8\end{array}$ & $\begin{array}{l}58.5 \\
44.5 \\
30.6 \\
17.6\end{array}$ & $\begin{array}{l}56.0 \\
42.2 \\
28.2 \\
14.1\end{array}$ & $\begin{array}{l}55.7 \\
46.4 \\
38.3 \\
32.3\end{array}$ \\
\hline & \multicolumn{2}{|c|}{12} & 60.0 & 30.0 & 20.0 & 10.0 & 0.0 & 30.0 \\
\hline
\end{tabular}

Feb. $21(-10.6)$ oct. $21(-10.7)$

\begin{tabular}{|c|c|c|c|c|c|c|c|}
\hline & & Horiz. & $L-10$ & tat. & Lat. +10 & Lat. + 20 & Vert. \\
\hline $\begin{array}{r}7 \\
8 \\
9 \\
10 \\
11\end{array}$ & $\begin{array}{l}5 \\
4 \\
3 \\
2 \\
1\end{array}$ & $\begin{array}{l}85.2 \\
74.6 \\
65.0 \\
57.2 \\
51.9\end{array}$ & $\begin{array}{r}77.2 \\
62.9 \\
49.0 \\
35.9 \\
.25 .0\end{array}$ & $\begin{array}{l}75.2 \\
60.5 \\
45.9 \\
31.5 \\
18.0\end{array}$ & $\begin{array}{l}73.7 \\
59.0 \\
44.3 \\
29.5 \\
14.8\end{array}$ & $\begin{array}{l}72.6 \\
58.5 \\
44.5 \\
30.6 \\
17.6\end{array}$ & $\begin{array}{l}72.7 \\
63.3 \\
59.5 \\
47.1 \\
41.9\end{array}$ \\
\hline \multicolumn{2}{|c|}{12} & 50.0 & 20.0 & 10.0 & 0.0 & 10.0 & 40.0 \\
\hline
\end{tabular}

Mar. $21(0.0)$

Sep. $21(0.0)$

\begin{tabular}{|r|c|c|c|c|c|c|c|}
\hline & & Horlz. & L-10 & Lat. & Lat. + 10 & Lat. + 20 & Vert. \\
\hline 7 & 5 & 78.6 & 75.2 & 75.0 & 75.2 & 75.9 & 80.4 \\
8 & 4 & 67.5 & 60.5 & 60.0 & 60.5 & 62.0 & 71.3 \\
9 & 3 & 57.2 & 45.9 & 45.0 & 45.9 & 48.4 & 63.0 \\
10 & 2 & 48.4 & 31.5 & 30.0 & 31.5 & 35.5 & 56.2 \\
11 & 1 & 42.3 & 18.0 & 15.0 & 18.0 & 24.8 & 51.6 \\
\hline \multicolumn{2}{|c|}{12} & 40.0 & 10.0 & 0.0 & 10.0 & 20.0 & 50.0 \\
\hline
\end{tabular}

Apr. $21(+11.9)$

\begin{tabular}{|r|c|c|c|c|c|c|c|}
\hline & & Horlz. & L - 10 & Lat. & Lat. + 10 & Lat. + 20 & Vert. \\
\hline 6 & 6 & 82.6 & 88.0 & 90.0 & 92.0 & 93.9 & 98.9 \\
7 & 5 & 71.1 & 73.5 & 75.3 & 77.6 & 80.2 & 89.5 \\
8 & 4 & 59.7 & 58.9 & 60.7 & 63.4 & 67.0 & 80.7 \\
9 & 3 & 48.7 & 44.2 & 46.2 & 49.7 & 54.4 & 73.1 \\
10 & 2 & 38.8 & 29.5 & 32.0 & 36.8 & 43.2 & 67.0 \\
11 & 1 & 31.3 & 14.8 & 18.9 & 26.2 & 34.9 & 63.0 \\
\hline \multicolumn{2}{|c|}{12} & 28.4 & 1.6 & 11.6 & 21.6 & 31.6 & 61.6 \\
\hline
\end{tabular}

May $21(+20.3)$

\begin{tabular}{|r|c|c|c|c|c|c|c|}
\hline & & Horlz. & $\mathrm{L}-10$ & \multicolumn{1}{c|}{ Lat. } & Lat. + 10 & Lat. + 20 & Vert. \\
\hline 5 & 2 & 88.1 & 100.4 & 104.1 & 107.4 & 110.2 & 114.7 \\
6 & 6 & 77.3 & 86.6 & 90.0 & 93.4 & 96.7 & 105.2 \\
7 & 5 & 66.0 & 72.6 & 75.9 & 79.6 & 83.6 & 96.1 \\
8 & 4 & 54.6 & 58.5 & 62.0 & 66.2 & 71.1 & 87.7 \\
9 & 3 & 43.2 & 44.5 & 48.4 & 53.5 & 59.5 & 80.5 \\
10 & 2 & 32.5 & 30.6 & 35.5 & 42.1 & 49.6 & 74.9 \\
11 & 1 & 23.8 & 17.6 & 24.8 & 33.4 & 42.6 & 71.2 \\
\hline \multicolumn{2}{|r|}{12} & 20.0 & 10.0 & 20.0 & 30.0 & 40.0 & 70.0 \\
\hline
\end{tabular}

\begin{tabular}{|c|c|c|c|c|c|c|c|}
\hline & & Horlz. & $\mathrm{L}-10$ & Lat. & Lat. + 10 & Lat. + 20 & Vert. \\
\hline 5 & 7 & 85.8 & 99.5 & 103.7 & 107.6 & 111.1 & 117.2 \\
5 & 6 & 75.2 & 86.0 & 90.0 & 94.0 & 97.8 & 107.7 \\
7 & 5 & 64.0 & 72.4 & 76.3 & 80.5 & 85.0 & 98.8 \\
8 & 4 & 52.6 & 58.6 & 62.7 & 67.5 & 72.8 & 90.6 \\
9 & 3 & 41.2 & 44.9 & 49.6 & 55.3 & 61.7 & 83.6 \\
10 & 2 & 30.2 & 31.6 & 37.4 & 44.5 & 52.4 & 78.1 \\
11 & 1 & 20.8 & 19.6 & 27.6 & 36.5 & 45.8 & 74.6 \\
\hline \multicolumn{1}{|c|}{12} & 16.6 & 13.4 & 23.4 & 33.4 & 43.4 & 73.4 \\
\hline
\end{tabular}




\begin{tabular}{|c|c|c|c|c|c|c|c|c|}
\hline \multirow{3}{*}{ Dec. $21(-23,45)$} & & & Horiz. & $L-10$ & Lat. & Lae. 10 & Lat. 20 & lert. \\
\hline & $\begin{array}{r}9 \\
10 \\
11\end{array}$ & $\begin{array}{l}3 \\
2 \\
1\end{array}$ & $\begin{array}{l}82.0 \\
76.4 \\
12.7\end{array}$ & $\begin{array}{l}55.3 \\
44.5 \\
36.5\end{array}$ & $\begin{array}{l}49.6 \\
37.4 \\
27.6\end{array}$ & $\begin{array}{l}44.9 \\
31.6 \\
19.6\end{array}$ & $\begin{array}{l}41.8 \\
28.0 \\
14.3\end{array}$ & $\begin{array}{l}41.6 \\
31.1 \\
22.4\end{array}$ \\
\hline & & & 71.4 & 33.4 & 23.4 & 13.5 & 3.5 & 18.5 \\
\hline
\end{tabular}

\begin{tabular}{|c|c|c|c|c|c|c|c|c|}
\hline \multirow{3}{*}{$\begin{array}{l}\text { Jon. } 21\left(\begin{array}{l}-19.9 \\
-19.9\end{array}\right) \\
\text { Nov. } 21\end{array}$} & & & Horiz. & $L \cdot 10$ & Lat. & Lat, +10 & Lat. 20 & vert. \\
\hline & $\begin{array}{r}8 \\
9 \\
10 \\
11\end{array}$ & $\begin{array}{l}4 \\
3 \\
2 \\
1\end{array}$ & $\begin{array}{l}86.5 \\
79.0 \\
73.1 \\
69.3\end{array}$ & $\begin{array}{l}56.2 \\
53.5 \\
42.1 \\
33.4\end{array}$ & $\begin{array}{l}62.0 \\
49.4 \\
35.5 \\
24.8\end{array}$ & $\begin{array}{l}58.5 \\
44.5 \\
30.6 \\
17.6\end{array}$ & $\begin{array}{l}56.0 \\
42.2 \\
28.2 \\
14.1\end{array}$ & $\begin{array}{l}54.7 \\
43.7 \\
33.5 \\
25 .\end{array}$ \\
\hline & & & 68.0 & 30.0 & 20.0 & 10.0 & 0.0 & 22.0 \\
\hline
\end{tabular}

\begin{tabular}{|c|c|c|c|c|c|c|c|c|}
\hline & & & Hortz. & $L \cdot 10$ & Lat. & Lat. + 10 & Lot. + 20 & vert. \\
\hline $\begin{array}{l}\text { Feb. } 21(-10.6) \\
\text { Oct. } 21(-10.7)\end{array}$ & $\begin{array}{r}7 \\
8 \\
9 \\
10 \\
11\end{array}$ & $\begin{array}{l}5 \\
4 \\
3 \\
2 \\
1\end{array}$ & $\begin{array}{l}87.6 \\
78.4 \\
70.3 \\
63.8 \\
59.5\end{array}$ & $\begin{array}{l}17.2 \\
62.9 \\
49.0 \\
35.9 \\
25.0\end{array}$ & $\begin{array}{l}75.2 \\
60.5 \\
45.9 \\
31.5 \\
18.0\end{array}$ & $\begin{array}{l}73.7 \\
59.0 \\
44.3 \\
29.5 \\
14.8\end{array}$ & $\begin{array}{l}72.6 \\
58.5 \\
44.5 \\
30.6 \\
17.6\end{array}$ & $\begin{array}{l}12.2 \\
61.2 \\
50.7 \\
41.4 \\
34.6\end{array}$ \\
\hline & 1 & & 58.0 & 20.0 & 10.0 & 0.0 & 10.0 & 32.0 \\
\hline
\end{tabular}

\begin{tabular}{|c|c|c|c|c|c|c|c|c|}
\hline & & & Hortz. & $t \cdot 10$ & Lot. & Lot. +10 & Lat. +20 & vert. \\
\hline $\begin{array}{l}\text { Mor. } 21 \\
\text { Sep. } 21\left(\begin{array}{l}0.0) \\
0.0\end{array}\right)\end{array}$ & $\begin{array}{r}7 \\
8 \\
9 \\
10 \\
11\end{array}$ & $\begin{array}{l}5 \\
4 \\
3 \\
2 \\
1\end{array}$ & $\begin{array}{l}80.0 \\
70.5 \\
61.8 \\
54.6 \\
49.7\end{array}$ & $\begin{array}{l}75.2 \\
60.5 \\
45.9 \\
31.5 \\
18.0\end{array}$ & $\begin{array}{l}15.0 \\
60.0 \\
45.0 \\
30.0 \\
15.0\end{array}$ & $\begin{array}{l}75.2 \\
60.5 \\
45.9 \\
31.5 \\
18.0\end{array}$ & $\begin{array}{l}75.9 \\
62.0 \\
48.4 \\
35.5 \\
24.8\end{array}$ & $\begin{array}{l}78.9 \\
68.2 \\
58.3 \\
49.9 \\
44.1\end{array}$ \\
\hline & 1 & & 48.0 & 10.0 & 0.0 & 10.0 & 20.0 & 42.0 \\
\hline
\end{tabular}

\begin{tabular}{|c|c|c|c|c|c|c|c|c|}
\hline \multirow{3}{*}{$\begin{array}{l}\text { Apr. } 21 \\
\text { Aug. } 21\end{array}\left(\begin{array}{l}+1 \\
+12.9 \\
12.1\end{array}\right)$} & & & Horiz. & $L-10$ & Lat. & Lat. + 10 & Lat. 20 & vert. \\
\hline & $\begin{array}{r}6 \\
7 \\
8 \\
9 \\
10 \\
11\end{array}$ & $\begin{array}{l}6 \\
5 \\
4 \\
3 \\
2 \\
1\end{array}$ & $\begin{array}{l}81.4 \\
71.4 \\
61.5 \\
52.2 \\
44.2 \\
38.5\end{array}$ & $\begin{array}{l}88.0 \\
73.5 \\
58.9 \\
44.2 \\
29.5 \\
14.8\end{array}$ & $\begin{array}{l}90.0 \\
75.3 \\
60.1 \\
46.2 \\
32.0 \\
18.9\end{array}$ & $\begin{array}{l}92.0 \\
17.6 \\
63.4 \\
49.7 \\
36.8 \\
26.2\end{array}$ & $\begin{array}{l}93.9 \\
80.2 \\
67.0 \\
54.4 \\
43.2 \\
34.9\end{array}$ & $\begin{array}{l}97.7 \\
86.9 \\
76.7 \\
67.7 \\
60.3 \\
55.3\end{array}$ \\
\hline & & & 36.4 & 1.6 & 11.6 & 21.6 & 31.6 & 53.6 \\
\hline
\end{tabular}

\begin{tabular}{|c|c|c|c|c|c|c|c|c|}
\hline \multirow[b]{2}{*}{$\begin{array}{l}\text { Moy } 21(+20.3) \\
\text { Jul. } 21(+20.5)\end{array}$} & & & Horiz. & $1-10$ & Lat. & Lat. + 10 & Lot. $\rightarrow \infty 0$ & vert. \\
\hline & $\begin{array}{r}5 \\
6 \\
7 \\
8 \\
9 \\
10 \\
11\end{array}$ & $\begin{array}{l}7 \\
6 \\
5 \\
4 \\
3 \\
2 \\
1\end{array}$ & $\begin{array}{l}84.8 \\
75.3 \\
65.4 \\
55.4 \\
45.7 \\
37.0 \\
30.5\end{array}$ & $\begin{array}{r}100.4 \\
66.6 \\
72.4 \\
58.5 \\
44.5 \\
30.6 \\
17.6\end{array}$ & $\begin{array}{r}104.1 \\
30.0 \\
75.9 \\
62.0 \\
48.4 \\
35.5 \\
24.8\end{array}$ & $\begin{array}{r}107.4 \\
93.4 \\
79.6 \\
66.2 \\
53.5 \\
42.1 \\
33.4\end{array}$ & $\begin{array}{r}110.2 \\
96.7 \\
83.6 \\
71.1 \\
59.5 \\
49.6 \\
42.6\end{array}$ & $\begin{array}{r}114.2 \\
103.2 \\
92.8 \\
83.1 \\
79.6 \\
67.9 \\
63.5\end{array}$ \\
\hline & & & 28.0 & 10.0 & 20.0 & 30.0 & 40.0 & 62.0 \\
\hline
\end{tabular}

\begin{tabular}{|c|c|c|c|c|c|c|c|c|}
\hline \multirow{2}{*}{ Jun. $21(+23.45)$} & & & Horiz. & $L-10$ & Lat. & Lat. * 10 & Lat. + 80 & vert. \\
\hline & $\begin{array}{r}5 \\
6 \\
7 \\
8 \\
9 \\
10 \\
11\end{array}$ & $\begin{array}{l}7 \\
6 \\
5 \\
4 \\
3 \\
2 \\
1\end{array}$ & $\begin{array}{l}82.1 \\
72.8 \\
63.0 \\
52.9 \\
43.1 \\
34.2 \\
27.3\end{array}$ & $\begin{array}{l}99.5 \\
86.0 \\
72.4 \\
58.6 \\
44.9 \\
31.6 \\
19.6\end{array}$ & $\begin{array}{r}103.7 \\
90.0 \\
76.3 \\
62.7 \\
49.6 \\
37.4 \\
27.6\end{array}$ & $\begin{array}{r}107.6 \\
94.0 \\
80.5 \\
67.5 \\
55.3 \\
41.5 \\
36.5\end{array}$ & $\begin{array}{r}111.8 \\
91.8 \\
85.0 \\
72.8 \\
61.8 \\
52.8 \\
45.8\end{array}$ & $\begin{array}{r}116.3 \\
105.4 \\
95.2 \\
85.7 \\
71.5 \\
11.1 \\
66.9\end{array}$ \\
\hline & & & 24.6 & 13.4 & 23.4 & 31.4 & 43.3 & E5.4 \\
\hline
\end{tabular}


TABLE A11 LATITUDE $56^{\circ} \mathrm{W}$. INCIDENT ANGLES FOR HORIZONTAL AND SOUTH-FACING TILTED SURFACES

\begin{tabular}{|c|c|c|c|c|c|c|c|c|}
\hline \multirow{3}{*}{ Dec. $21(-23.45)$} & & & Horlz. & $1 \cdot 10$ & lat. & Lat. + 10 & LAt. - 70 & vert. \\
\hline & $\begin{array}{r}9 \\
10 \\
11\end{array}$ & $\begin{array}{l}3 \\
2 \\
1\end{array}$ & $\begin{array}{l}89.1 \\
83.4 \\
80.5\end{array}$ & $\begin{array}{l}55.3 \\
44.5 \\
36.5\end{array}$ & $\begin{array}{l}49.6 \\
37.4 \\
27.6\end{array}$ & $\begin{array}{l}44.9 \\
31.6 \\
19.6\end{array}$ & $\begin{array}{l}41.8 \\
28.0 \\
14.3\end{array}$ & $\begin{array}{l}40.5 \\
28.2 \\
16.8\end{array}$ \\
\hline & 1 & & 79.4 & 33.4 & 23.4 & 13.5 & 3.4 & 10.5 \\
\hline
\end{tabular}

\begin{tabular}{|c|c|c|c|c|c|c|c|c|}
\hline \multirow{3}{*}{ 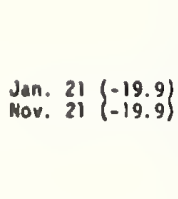 } & & & Horiz. & $L \cdot 10$ & lat. & tat. +10 & tat. 20 & vert. \\
\hline & $\begin{array}{r}9 \\
10 \\
11\end{array}$ & $\begin{array}{l}3 \\
2 \\
1\end{array}$ & $\begin{array}{l}85.0 \\
80.1 \\
77.1\end{array}$ & $\begin{array}{l}53.5 \\
42.1 \\
33.4\end{array}$ & $\begin{array}{l}48.4 \\
35.5 \\
24.8\end{array}$ & $\begin{array}{l}44.5 \\
30.6 \\
17.6\end{array}$ & $\begin{array}{l}42.2 \\
28.2 \\
14.1\end{array}$ & $\begin{array}{l}42.1 \\
30.0 \\
19.3\end{array}$ \\
\hline & & & 76.0 & 30.0 & 20.0 & 10.0 & 0.0 & 14.0 \\
\hline
\end{tabular}

\begin{tabular}{|c|c|c|c|c|c|c|c|c|}
\hline \multirow{3}{*}{$\begin{array}{l}\text { Feb. } 21(-10.6) \\
\text { Oct. } 21(-10.7)\end{array}$} & & & Horiz. & $1 \cdot 10$ & LAt. & lat. 10 & Lat. 20 & Vert. \\
\hline & $\begin{array}{r}8 \\
9 \\
10 \\
11\end{array}$ & $\begin{array}{l}4 \\
3 \\
2 \\
1\end{array}$ & $\begin{array}{l}82.5 \\
75.8 \\
70.6 \\
67.2\end{array}$ & $\begin{array}{l}62.9 \\
49.0 \\
35.9 \\
25.0\end{array}$ & $\begin{array}{l}60.5 \\
45.9 \\
31.5 \\
18.0\end{array}$ & $\begin{array}{l}59.0 \\
44.3 \\
29.5 \\
14.8\end{array}$ & $\begin{array}{l}58.5 \\
44.5 \\
30.6 \\
17.6\end{array}$ & $\begin{array}{l}59.6 \\
97.6 \\
36.5 \\
27.7\end{array}$ \\
\hline & & & 66.0 & 20.0 & 10.0 & 0.0 & 10.0 & 24.0 \\
\hline & & & & & & & & \\
\hline
\end{tabular}

\begin{tabular}{|c|c|c|c|c|c|c|c|c|}
\hline \multirow[b]{2}{*}{ 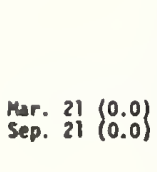 } & & & Horiz. & $L=10$ & Lat. & tat. + 10 & Lat. 20 & Fert. \\
\hline & $\begin{array}{r}7 \\
8 \\
9 \\
10 \\
11\end{array}$ & $\begin{array}{l}5 \\
4 \\
3 \\
2 \\
1\end{array}$ & $\begin{array}{l}81.7 \\
73.9 \\
66.7 \\
61.0 \\
57.3\end{array}$ & $\begin{array}{l}75.2 \\
60.5 \\
45.9 \\
31.5 \\
18.0\end{array}$ & $\begin{array}{l}75.0 \\
60.0 \\
45.0 \\
30.0 \\
15.0\end{array}$ & $\begin{array}{l}75.2 \\
60.5 \\
45.9 \\
31.5 \\
18.0\end{array}$ & $\begin{array}{l}75.9 \\
62.0 \\
48.4 \\
35.5 \\
24.8\end{array}$ & $\begin{array}{l}77.6 \\
65.0 \\
54.1 \\
44.1 \\
36.8\end{array}$ \\
\hline - & & & 56.0 & 10.0 & 0.0 & 10.0 & 20.0 & 34.0 \\
\hline
\end{tabular}

\begin{tabular}{|c|c|c|c|c|c|c|c|c|}
\hline \multirow{3}{*}{$\begin{array}{l}\text { Apr. } 21 \quad(+11,9) \\
\text { Aug. } 21(+12,1)\end{array}$} & & & Horiz. & $L \cdot 10$ & Lat. & Lat. 10 & Lat. +20 & vert. \\
\hline & $\begin{array}{r}5 \\
6 \\
7 \\
8 \\
9 \\
10 \\
11\end{array}$ & $\begin{array}{l}7 \\
6 \\
5 \\
4 \\
3 \\
2 \\
1\end{array}$ & $\begin{array}{l}83.6 \\
80.4 \\
72.0 \\
63.9 \\
56.4 \\
50.1 \\
45.9\end{array}$ & $\begin{array}{r}102.4 \\
88.0 \\
73.5 \\
58.9 \\
44.2 \\
29.5 \\
14.8\end{array}$ & $\begin{array}{r}104.7 \\
90.0 \\
75.3 \\
60.7 \\
46.2 \\
32.0 \\
18.9\end{array}$ & $\begin{array}{r}106.5 \\
92.0 \\
77.6 \\
63.4 \\
49.7 \\
36.8 \\
26.2\end{array}$ & $\begin{array}{r}107.9 \\
93.9 \\
80.2 \\
67.0 \\
54.4 \\
43.2 \\
34.9\end{array}$ & $\begin{array}{r}108.8 \\
96.5 \\
84.4 \\
12.9 \\
62.5 \\
53.8 \\
47.8\end{array}$ \\
\hline & & 12 & 44.4 & 1.6 & 11.6 & 21.6 & 31.6 & 45.6 \\
\hline
\end{tabular}

\begin{tabular}{|c|c|c|c|c|c|c|c|c|}
\hline \multirow[b]{2}{*}{$\begin{array}{l}\text { Moy } 21 \quad(+20.3) \\
\text { Jul. } 21(+20.5)\end{array}$} & & & Horiz. & L. 10 & Lat. & tat. 10 & (at. - 3) & vert. \\
\hline & $\begin{array}{c}1 \\
5 \\
6 \\
7 \\
8 \\
9 \\
10 \\
11\end{array}$ & $\begin{array}{l}8 \\
7 \\
6 \\
5 \\
4 \\
3 \\
2 \\
1\end{array}$ & $\begin{array}{l}88.8 \\
81.5 \\
73.5 \\
65.2 \\
56.9 \\
49.1 \\
42.4 \\
37.7\end{array}$ & $\begin{array}{r}113.8 \\
100.4 \\
186.6 \\
72.6 \\
58.5 \\
44.5 \\
30.6 \\
17.6\end{array}$ & $\begin{array}{r}118.0 \\
104.1 \\
30.0 \\
75.9 \\
62.0 \\
48.4 \\
35.5 \\
24.8\end{array}$ & $\begin{array}{r}121.5 \\
107.4 \\
93.4 \\
79.6 \\
66.2 \\
53.5 \\
42.1 \\
33.4\end{array}$ & $\begin{array}{r}124.0 \\
110.2 \\
96.7 \\
83.6 \\
71.1 \\
59.5 \\
49.6 \\
42.6\end{array}$ & $\begin{array}{r}125.5 \\
113.1 \\
101.0 \\
89.4 \\
78.6 \\
68.9 \\
61.1 \\
55.9\end{array}$ \\
\hline & 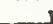 & & 160 & in 0 & $=0$ & ח & An 0 & 540 \\
\hline
\end{tabular}

\begin{tabular}{|c|c|c|c|c|c|c|c|c|}
\hline \multirow{2}{*}{ Jun. $21(+23.45)$} & & & Horiz. & L. 10 & tat. & Lat. * 10 & Lat. + 20 & vert. \\
\hline & $\begin{array}{r}4 \\
5 \\
6 \\
7 \\
8 \\
9 \\
10 \\
11\end{array}$ & $\begin{array}{l}8 \\
7 \\
6 \\
3 \\
4 \\
3 \\
2 \\
1\end{array}$ & $\begin{array}{l}85.8 \\
78.6 \\
70.7 \\
62.4 \\
54.1 \\
46.2 \\
39.3 \\
34.4\end{array}$ & $\begin{array}{r}112.5 \\
99.5 \\
86.0 \\
72.4 \\
58.6 \\
44.9 \\
31.6 \\
19.6\end{array}$ & $\begin{array}{r}117.3 \\
103.3 \\
90.0 \\
76.3 \\
62.7 \\
49.6 \\
37.4 \\
27.6\end{array}$ & $\begin{array}{r}121.4 \\
117.6 \\
94.0 \\
80.5 \\
67.5 \\
55.3 \\
44.5 \\
36.5\end{array}$ & $\begin{array}{r}124.6 \\
111.1 \\
97.8 \\
85.0 \\
72.8 \\
61.7 \\
52.4 \\
45.8\end{array}$ & $\begin{array}{r}127.1 \\
111.8 \\
102.9 \\
91.5 \\
80.9 \\
71.6 \\
64.1 \\
59.2\end{array}$ \\
\hline & & & 32.6 & 13.4 & 23.4 & 33.4 & 43.4 & 57.4 \\
\hline
\end{tabular}


TABLE A12 LATITUDE $64^{\circ} \mathrm{i}$. INCIDENT ANGLES FOR HORIZONTAL AND SOUIH-FACING TILTED SURFACES

\begin{tabular}{|c|c|c|c|c|c|c|c|c|}
\hline \multirow{3}{*}{ Dec. $21(-23.45)$} & & & Horiz. & $L \cdot 10$ & Lat. & Lat. + 10 & Lat. + 20 & vert. \\
\hline & 11 & 1 & 88.2 & 36.5 & 27.6 & 19.6 & 14.3 & 13.9 \\
\hline & & & 87.4 & 33.4 & 23.4 & 13.5 & 3.4 & 2.5 \\
\hline
\end{tabular}

\begin{tabular}{|c|c|c|c|c|c|c|c|c|}
\hline \multirow{3}{*}{$\begin{array}{l}\text { Jan. } 21\left(\begin{array}{rl}-19.9) \\
\text { Mov. } 21\end{array}(-19.9)\right.\end{array}$} & & & Horix. & $L \cdot 10$ & Lat. & Lat. 10 & Lat. + 20 & vert. \\
\hline & $\begin{array}{l}10 \\
11\end{array}$ & $?$ & $\begin{array}{l}87.2 \\
84.8\end{array}$ & $\begin{array}{l}42.1 \\
33.4\end{array}$ & $\begin{array}{l}35.5 \\
24.8\end{array}$ & $\begin{array}{l}30.6 \\
17.6\end{array}$ & $\begin{array}{l}28.2 \\
14.1\end{array}$ & $\begin{array}{l}28.2 \\
15.0\end{array}$ \\
\hline & & & 84.0 & 30.0 & 20.0 & 10.0 & 0.0 & , 6.0 \\
\hline
\end{tabular}

\begin{tabular}{|c|c|c|c|c|c|c|c|c|}
\hline \multirow{3}{*}{$\left.\begin{array}{l}\text { reb. } 21 \\
\text { Oct. } 21 \\
\text { oct } \\
-10.6 \\
-10.7\end{array}\right\}$} & & & Morlz. & $L-10$ & Lat. & Lot. 10 & Lae. 20 & vert. \\
\hline & $\begin{array}{r}8 \\
9 \\
10 \\
11\end{array}$ & $\begin{array}{l}4 \\
3 \\
2 \\
1\end{array}$ & $\begin{array}{l}86.6 \\
81.4 \\
71.4 \\
74.9\end{array}$ & $\begin{array}{l}62.9 \\
49.0 \\
35.9 \\
25.0\end{array}$ & $\begin{array}{l}60.5 \\
45.9 \\
31.5 \\
18.0\end{array}$ & $\begin{array}{l}59.0 \\
44.3 \\
29.5 \\
14.8\end{array}$ & $\begin{array}{l}58.5 \\
44.5 \\
30.6 \\
17.6\end{array}$ & $\begin{array}{l}58.8 \\
45.4 \\
32.6 \\
21.4\end{array}$ \\
\hline & & 2 & 74.0 & 20.0 & 10.0 & 0.0 & 10.0 & 16.0 \\
\hline
\end{tabular}

\begin{tabular}{|c|c|c|c|c|c|c|c|c|}
\hline \multirow{3}{*}{$\begin{array}{l}\text { Mer. } 21 \\
\text { Sep. } 21\end{array}\left\{\begin{array}{l}0.0 \\
0.0\end{array}\right\}$} & & & Morlz. & $L \cdot 10$ & Lat. & Lat. + 10 & Lel. +20 & vert. \\
\hline & $\begin{array}{r}7 \\
8 \\
9 \\
10 \\
11\end{array}$ & $\begin{array}{l}5 \\
4 \\
3 \\
2 \\
1\end{array}$ & $\begin{array}{l}83.5 \\
77.3 \\
11.9 \\
67.7 \\
64.9\end{array}$ & $\begin{array}{l}75.2 \\
60.5 \\
45.9 \\
31.5 \\
18.0\end{array}$ & $\begin{array}{l}75.0 \\
60.0 \\
45.0 \\
30.0 \\
15.0\end{array}$ & $\begin{array}{l}75.2 \\
60.5 \\
45.9 \\
31.5 \\
18.0\end{array}$ & $\begin{array}{l}75.9 \\
62.0 \\
48.4 \\
35.5 \\
24.8\end{array}$ & $\begin{array}{l}76.5 \\
63.3 \\
50.5 \\
38.9 \\
29.8\end{array}$ \\
\hline & & & 64.0 & 10.0 & 0.0 & 10.0 & 20.0 & 26.0 \\
\hline
\end{tabular}

\begin{tabular}{|c|c|c|c|c|c|c|c|c|}
\hline \multirow{3}{*}{$\begin{array}{l}\text { Apr. } 21\left(\begin{array}{l}11.9\} \\
\text { Aug. } 21\end{array}+12.1\right\}\end{array}$} & & & Horiz. & $L-10$ & Lat. & Lat. 10 & Lat. 20 & vert. \\
\hline & $\begin{array}{r}5 \\
6 \\
7 \\
8 \\
9 \\
10 \\
11\end{array}$ & $\begin{array}{l}7 \\
6 \\
5 \\
4 \\
3 \\
2 \\
1\end{array}$ & $\begin{array}{l}76.0 \\
79.6 \\
73.0 \\
66.7 \\
61.0 \\
56.5 \\
53.5\end{array}$ & $\begin{array}{r}102.4 \\
88.0 \\
73.5 \\
58.9 \\
44.2 \\
29.5 \\
14.8\end{array}$ & $\begin{array}{r}104.7 \\
90.0 \\
75.3 \\
60.7 \\
46.2 \\
32.0 \\
18.9\end{array}$ & $\begin{array}{r}106.5 \\
92.0 \\
77.6 \\
63.4 \\
49.7 \\
36.8 \\
26.2\end{array}$ & $\begin{array}{r}107.9 \\
33.9 \\
80.2 \\
67.0 \\
54.4 \\
43.2 \\
34.9\end{array}$ & $\begin{array}{r}103.4 \\
95.1 \\
82.0 \\
69.4 \\
57.7 \\
47.6 \\
40.3\end{array}$ \\
\hline & & & 52.4 & 1.6 & 11.6 & 21.6 & 31.6 & 31.6 \\
\hline
\end{tabular}

\begin{tabular}{|c|c|c|c|c|c|c|c|c|}
\hline \multirow{3}{*}{$\begin{array}{l}\operatorname{May} 21(+20.3) \\
\text { Jui. } 21(+20.5)\end{array}$} & & & Horiz. & $L \cdot 10$ & Lst. & Lot. +10 & let. 20 & vert. \\
\hline & $\begin{array}{c}4 \\
5 \\
6 \\
7 \\
8 \\
9 \\
10 \\
11\end{array}$ & $\begin{array}{l}8 \\
7 \\
6 \\
5 \\
4 \\
3 \\
2 \\
1\end{array}$ & $\begin{array}{l}84.2 \\
78.4 \\
72.1 \\
65.5 \\
59.1 \\
53.2 \\
48.4 \\
45.1\end{array}$ & $\begin{array}{r}113.8 \\
100.4 \\
86.6 \\
12.6 \\
58.5 \\
44.5 \\
30.6 \\
17.6\end{array}$ & $\begin{array}{r}118.0 \\
104.1 \\
90.0 \\
75.9 \\
62.0 \\
48.4 \\
35.5 \\
24.8\end{array}$ & $\begin{array}{r}121.5 \\
107.4 \\
93.4 \\
79.6 \\
66.2 \\
53.5 \\
42.1 \\
33.4\end{array}$ & $\begin{array}{r}124.0 \\
110.2 \\
96.7 \\
83.6 \\
11.1 \\
59.5 \\
49.6 \\
42.6\end{array}$ & $\begin{array}{r}124.9 \\
111.6 \\
98.6 \\
86.1 \\
78.2 \\
63.4 \\
54.4 \\
48.3\end{array}$ \\
\hline & 1 & & 44.0 & 10.0 & 20.0 & 30.0 & 40.0 & 46.0 \\
\hline
\end{tabular}

\begin{tabular}{|c|c|c|c|c|c|c|c|c|}
\hline & & & Horlz. & $L \cdot 10$ & Lat. & Lat. + 10 & Let. 20 & Vert. \\
\hline Jun. $21(+23.45)$ & $\begin{array}{r}3 \\
4 \\
5 \\
6 \\
7 \\
8 \\
9 \\
10 \\
11 \\
\end{array}$ & $\begin{array}{l}9 \\
8 \\
7 \\
6 \\
5 \\
4 \\
3 \\
2 \\
1\end{array}$ & $\begin{array}{l}85.8 \\
81.0 \\
75.3 \\
69.0 \\
62.5 \\
56.0 \\
50.1 \\
45.1 \\
41.7 \\
40.6\end{array}$ & $\begin{array}{r}121.7 \\
112.5 \\
99.5 \\
86.0 \\
72.4 \\
58.6 \\
44.9 \\
31.6 \\
19.6 \\
13.5\end{array}$ & $\begin{array}{r}130.4 \\
117.3 \\
103.7 \\
90.0 \\
76.3 \\
62.7 \\
49.6 \\
31.4 \\
27.6 \\
23\end{array}$ & $\begin{array}{r}135.1 \\
121.4 \\
107.6 \\
94.0 \\
30.5 \\
67.5 \\
55.6 \\
44.5 \\
36.5 \\
114\end{array}$ & $\begin{array}{r}139.2 \\
124.6 \\
111.1 \\
97.8 \\
85.0 \\
72.8 \\
61.7 \\
52.4 \\
45.6\end{array}$ & $\begin{array}{r}139.2 \\
125.9 \\
112.8 \\
100.0 \\
87.8 \\
76.2 \\
65.9 \\
57.3 \\
51.5 \\
49.9\end{array}$ \\
\hline
\end{tabular}


Date X

Observer (s) X

Equipment name plate data

X

X

Collector tilt angle

X

X

Collector azimuth angle (as a function of time if movable)

X

X

Collector aperture area or frontal transparent area

X

$\mathrm{X}$

Local standard time, at the beginning of collector warm-up and at the beginning and end of each 15 minute test period

$\mathrm{X}$

$\mathrm{X}$

Barometric pressure

$\mathrm{X}$

Ambient air temperature (at the beginning and end of each 15 minute test period)

$\mathrm{X}$

$\mathrm{X}$

$\Delta t=t_{f, e}-t_{f, i}$ across solar collector (either as a continuous function of time or as a 15 minute integrated quantity)

$\mathrm{X}$

$\mathrm{X}$

Inlet temperature, $t_{f, i}$ (as a continuous function of time

$\mathrm{X}$

$\mathrm{X}$

Outlet temperature, $t_{f, e}$ (as a continuous function of time

X

X 
Liquid flow rate

Gauge pressure at solar collector inlet

Gauge pressure at nozzle throat

Nozzle throat diameter

$\mathrm{X}$

Velocity pressure at nozzle throat or static pressure difference across nozzle

Dry bulb temperature at nozzle throat

$\mathrm{X}$

Wet bulb temperature at nozzle throat

$\mathrm{X}$

Pressure drop across solar collector

$\mathrm{X}$

$\mathrm{X}$

Height of the collector out let above the collector in let

$\mathrm{X}$

$\mathrm{X}$

Wind velocity near the collector surface or aperture ( 15 minute average)

I, the incident solar radiation onto the collector (as a continuous function of time and as a 15 minute integrated quantity if desired)

$I_{d}$, the diffuse component of the solar radiation onto the collector (at the beginning of the 15 minute period and after the completion of the 15 minute period) 
General Information

Manufacturer or Project Name . . . . . . . . . . . . . . . . Collector Model No..........

Construction details of the collector

gross dimensions and area . . . . . . . . . . . . . . . . area of absorbing surface . . . . . . . . . . . . . . . . . . cover plate*, dimensions, materials, optical properties (if known). . reflector*, dimensions and shape, materials, optical properties (if

known) . . . . . . . . . . . . . . . . . . . . . . absorber plate, dimensional layout and configuration of flow path, absorptivity to short wave radiation (if known), emissivity for long wave radiation (if known), description of coating (including maximum allowable temperature if known) . . . . . . . . . . . air space $(\mathrm{s}) *$, thickness and description of contained gas or construction . . . . . . . . . . . . . . . . . . . . . . . . . insulation*, material, thickness, thermal properties . . . . . . .

Transfer fluid used and its properties . . . . . . . . . . . . . . Weight of collector per $\mathrm{m}^{2}$ of gross cross-sectional area . . . . . . . Volumetric capacity of the collector per $\mathrm{m}^{2}$ of gross cross-sectional area if designed to operate with a liquid as the transfer fluid

Normal operating temperature range . . . . . . . . . . . . . . . . Minimum transfer fluid flow rate . . . . . . . . . . . . . . . Maximum transfer fluid flow rate . . . . . . . . . . . . . . . Maximum operating pressure . . . . . . . . . . . . . . . . .

Description of apparatus, including flow configuration and instrumentation used in testing (include photographs) . . . . . . . . . . .

Description of the mounting of the collector for testing Location of tests (longitude, latitude, and elevation above see level)

\section{Efficiency Tests}

A plot of the efficiency versus $\left(\frac{t_{f_{2} i}+t_{f, e}}{2}-t_{a} / / I \ldots \ldots . . . .\right.$.

* if applicable 
An equation for the efficiency curve . . . . . . . . . . . . . . For each "data point"

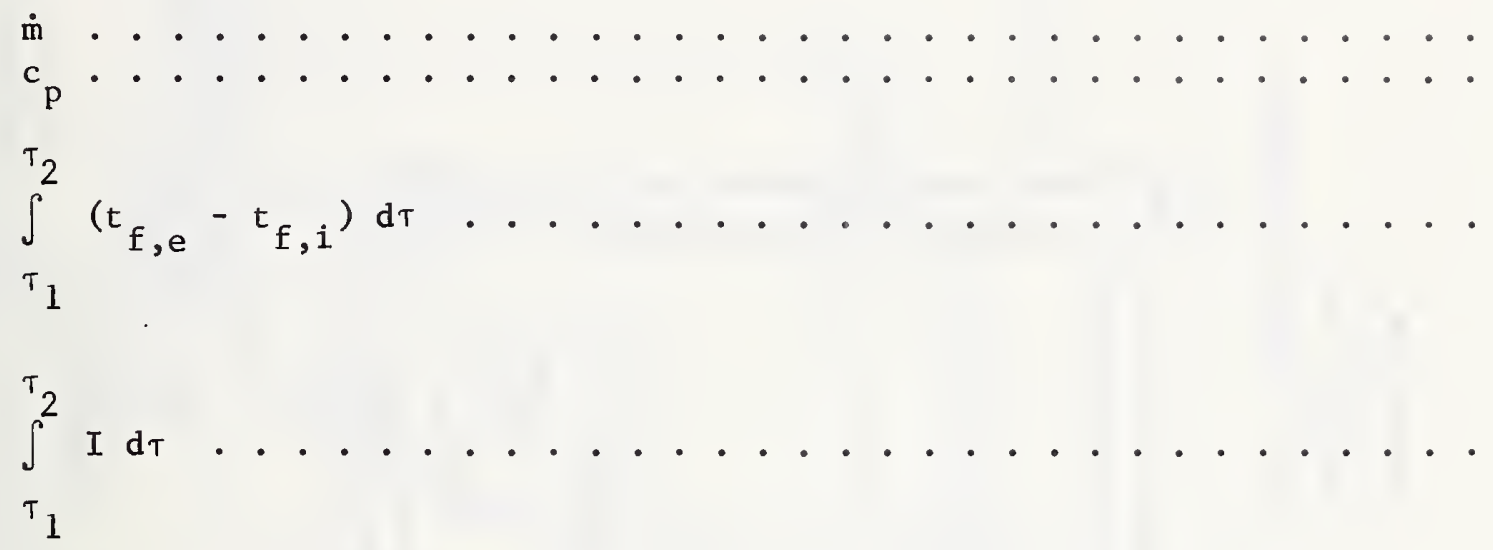

pressure drop across the solar collector . . . . . . . . . . . . collector tilt angle . . . . . . . . . . . . . . . . . collector azimuth angle (as a function of time if movable)...... incident angle . . . . . . . . . . . . . . . . . . . . . .

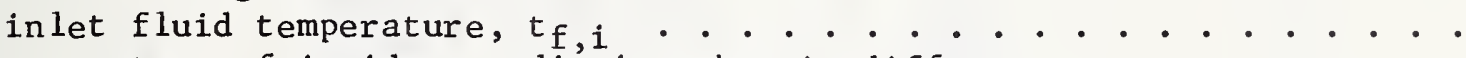
percentage of incident radiation that is diffuse . . . . . . . . . . wind speed near the collector surface or aperture . . . . . . . . . . 


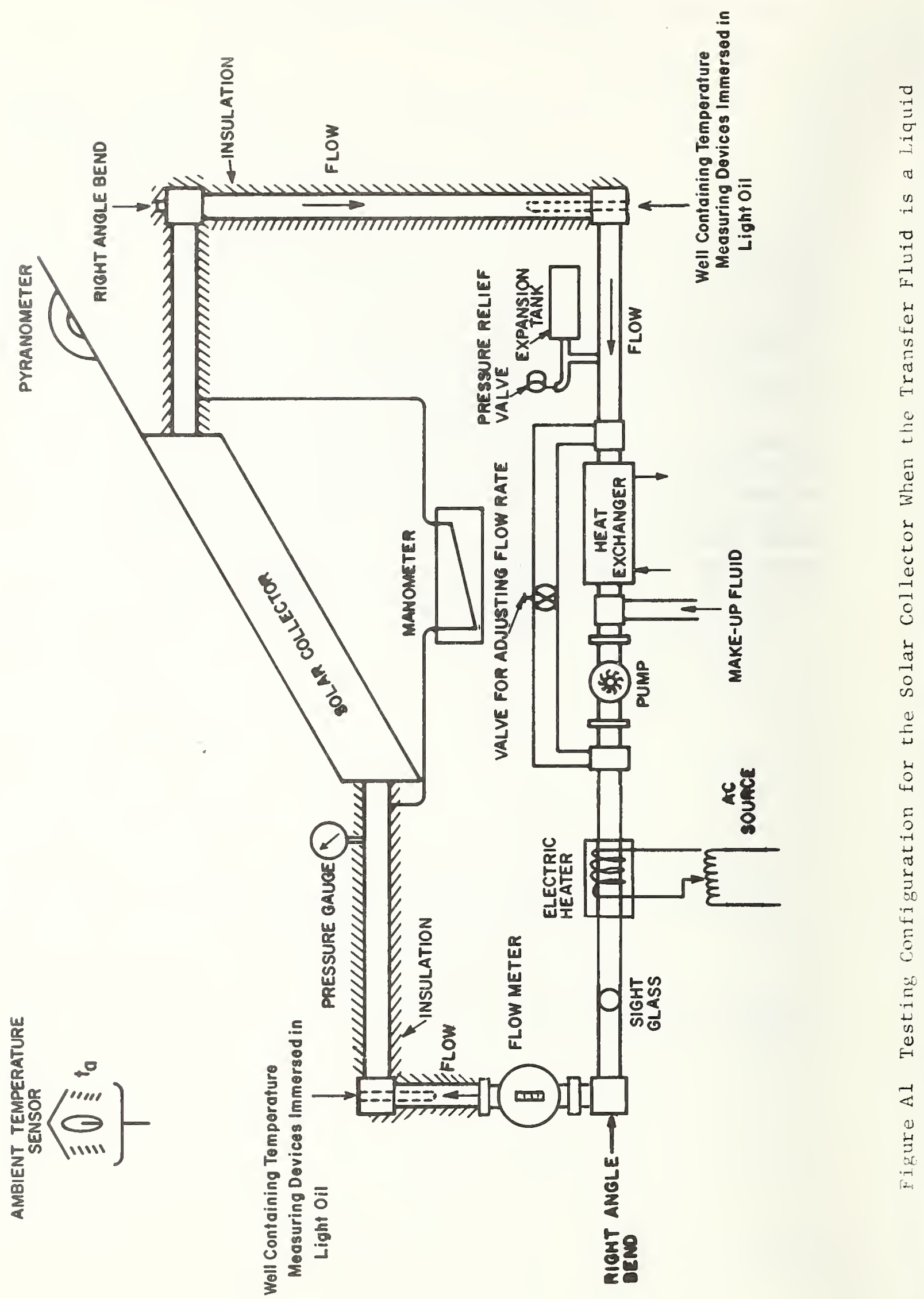




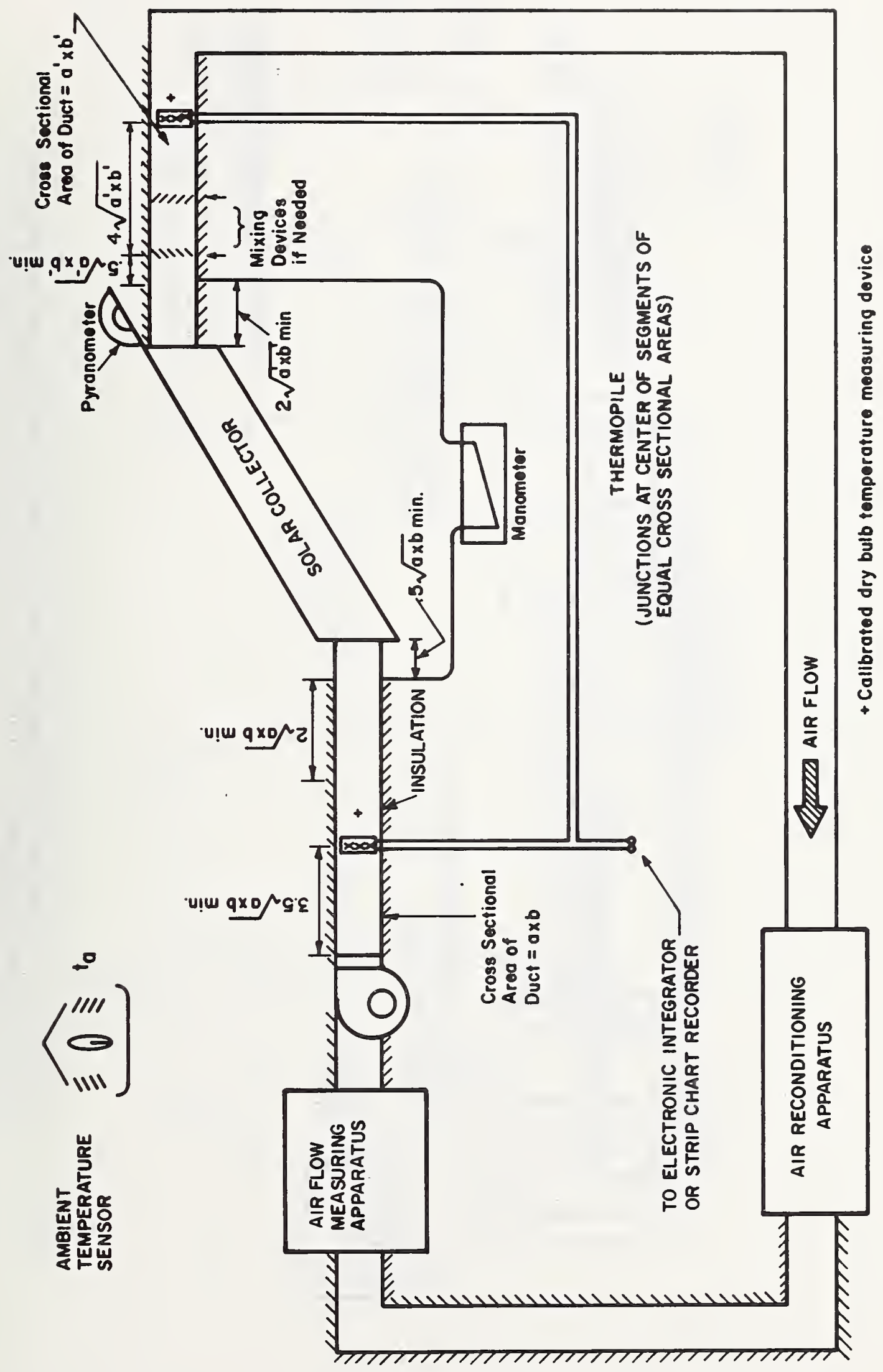

ב⿱ 


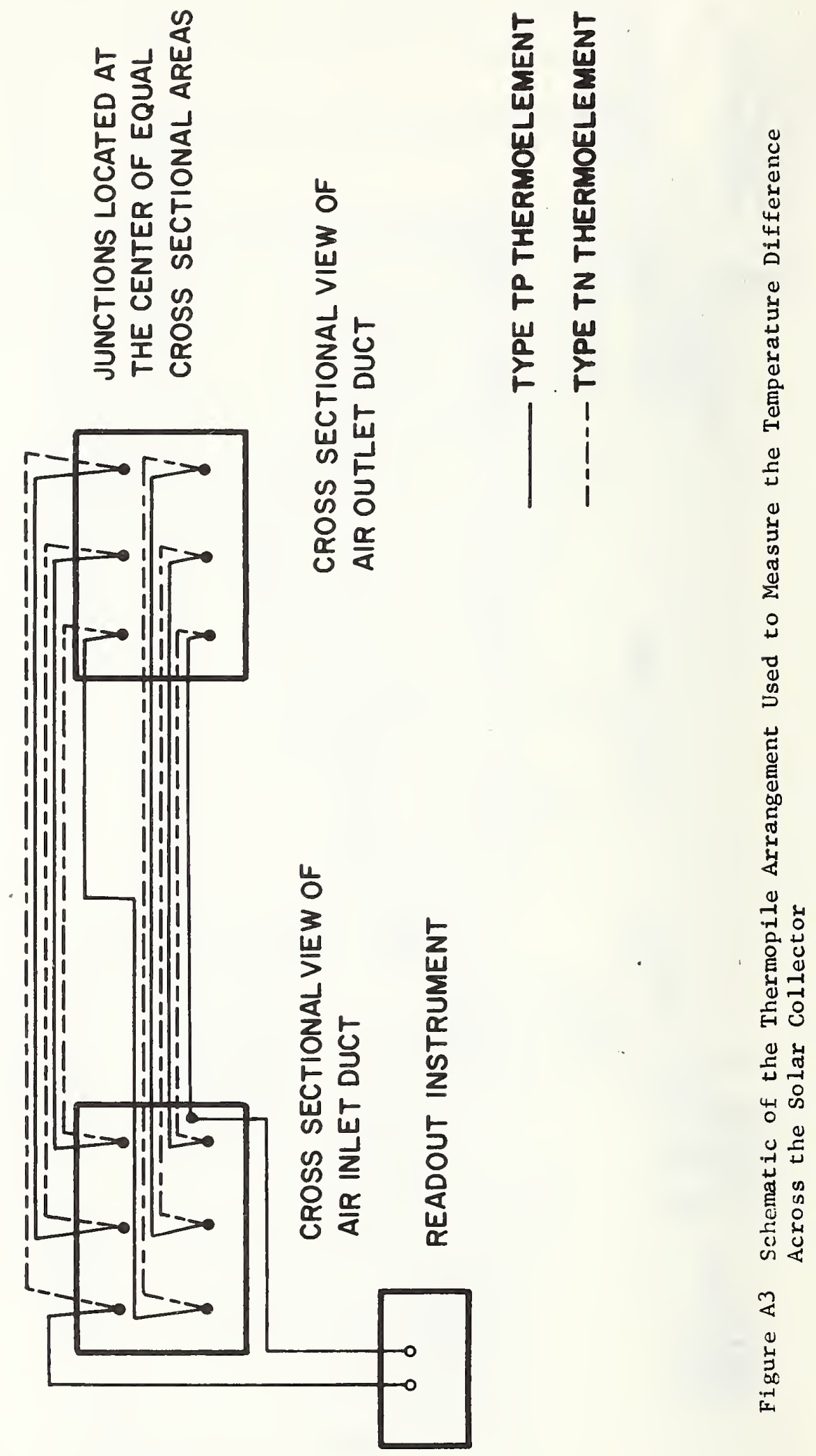




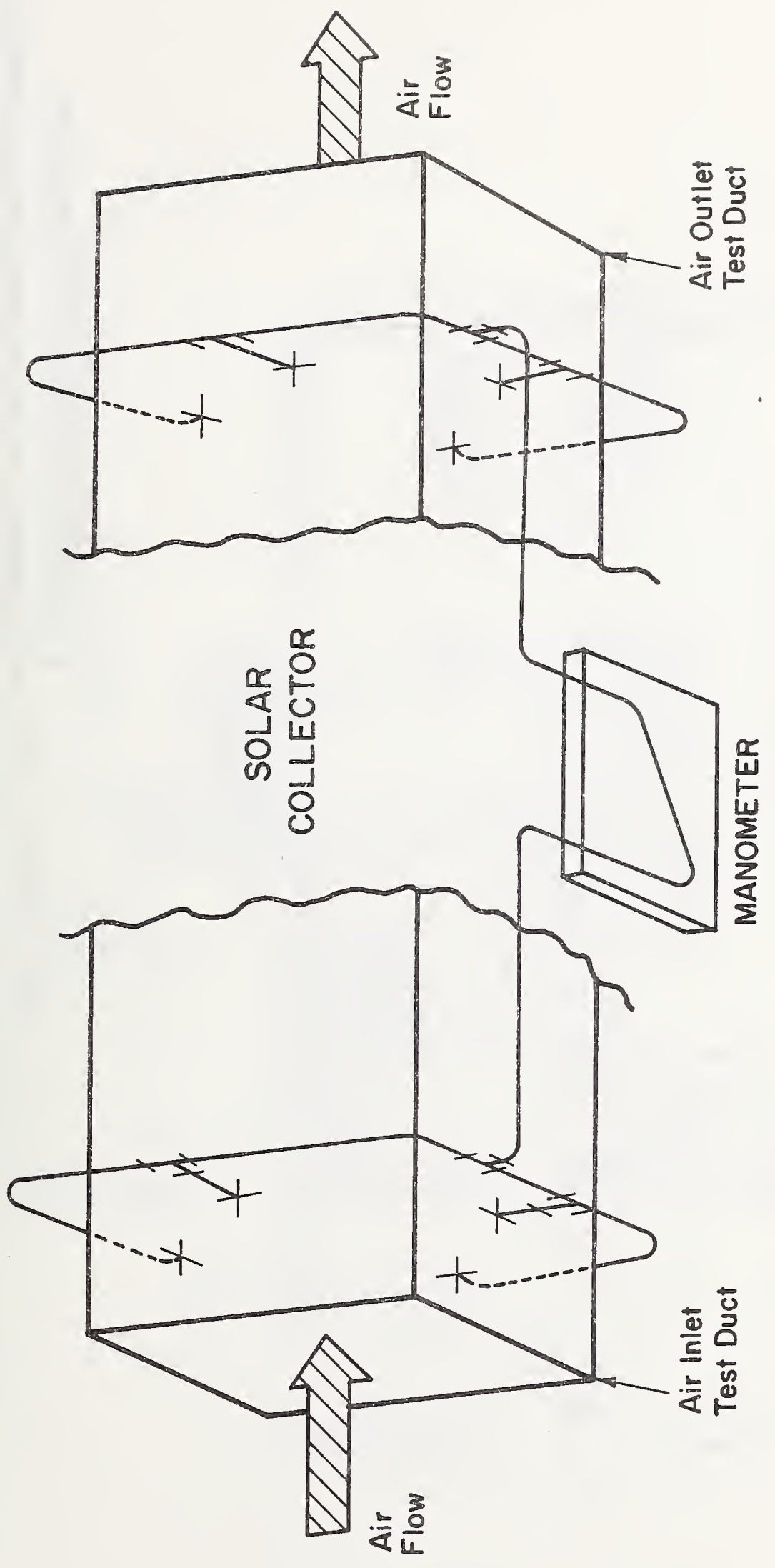

2
0
0
0
0
-1
0
0

4
-
-1
0
0

는

\begin{tabular}{l}
$n$ \\
0 \\
0 \\
4 \\
$y$ \\
\multirow{4}{4}{}
\end{tabular}

ํ.

岁

4

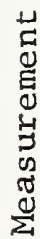

冚

D.

is कs

๘

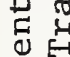

क

近

电的

0

넘

ष

造

要

崩 
통

늠

品 등

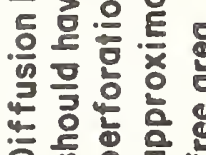

$\frac{\ddot{0}}{2}$

告

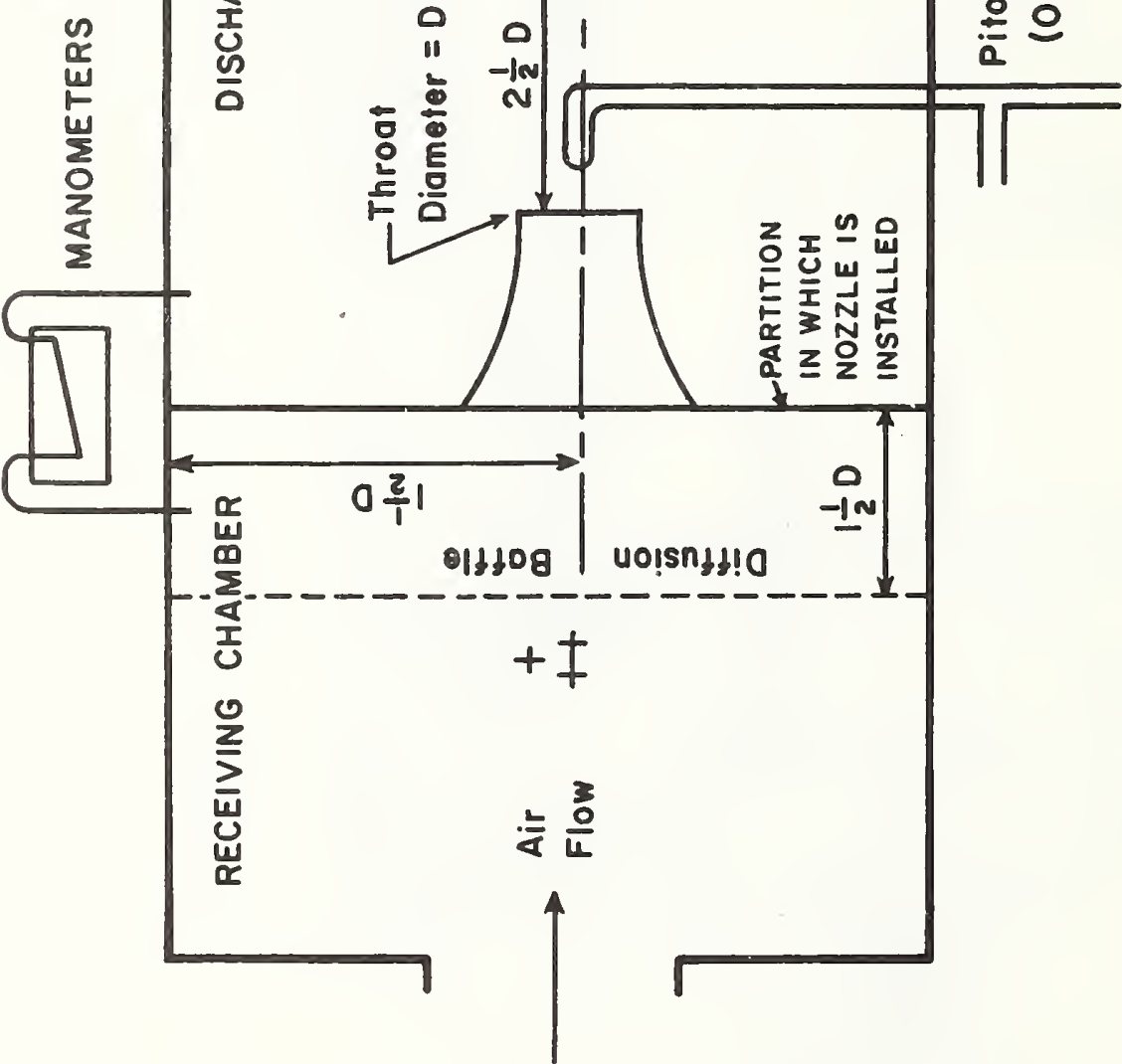




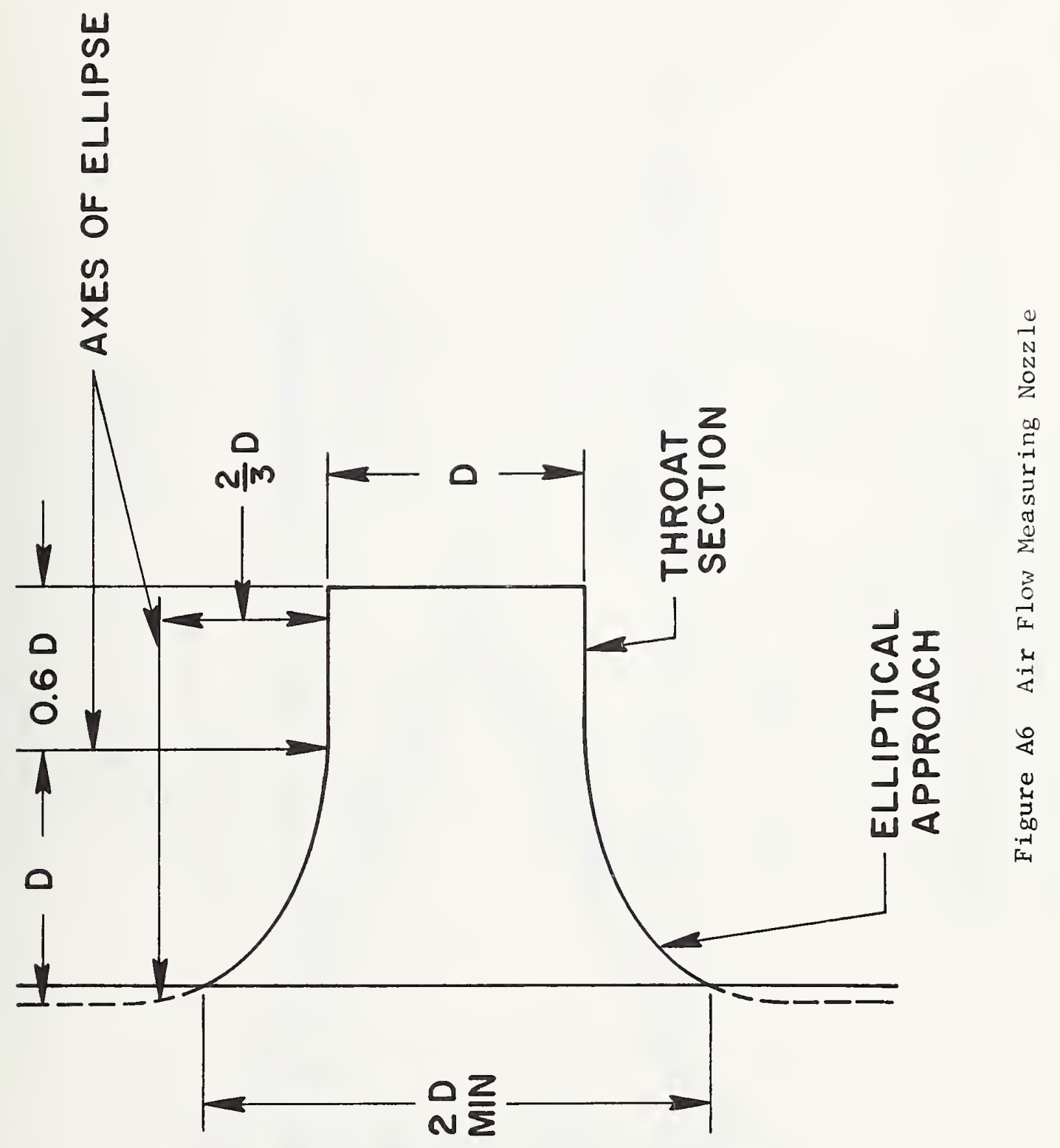



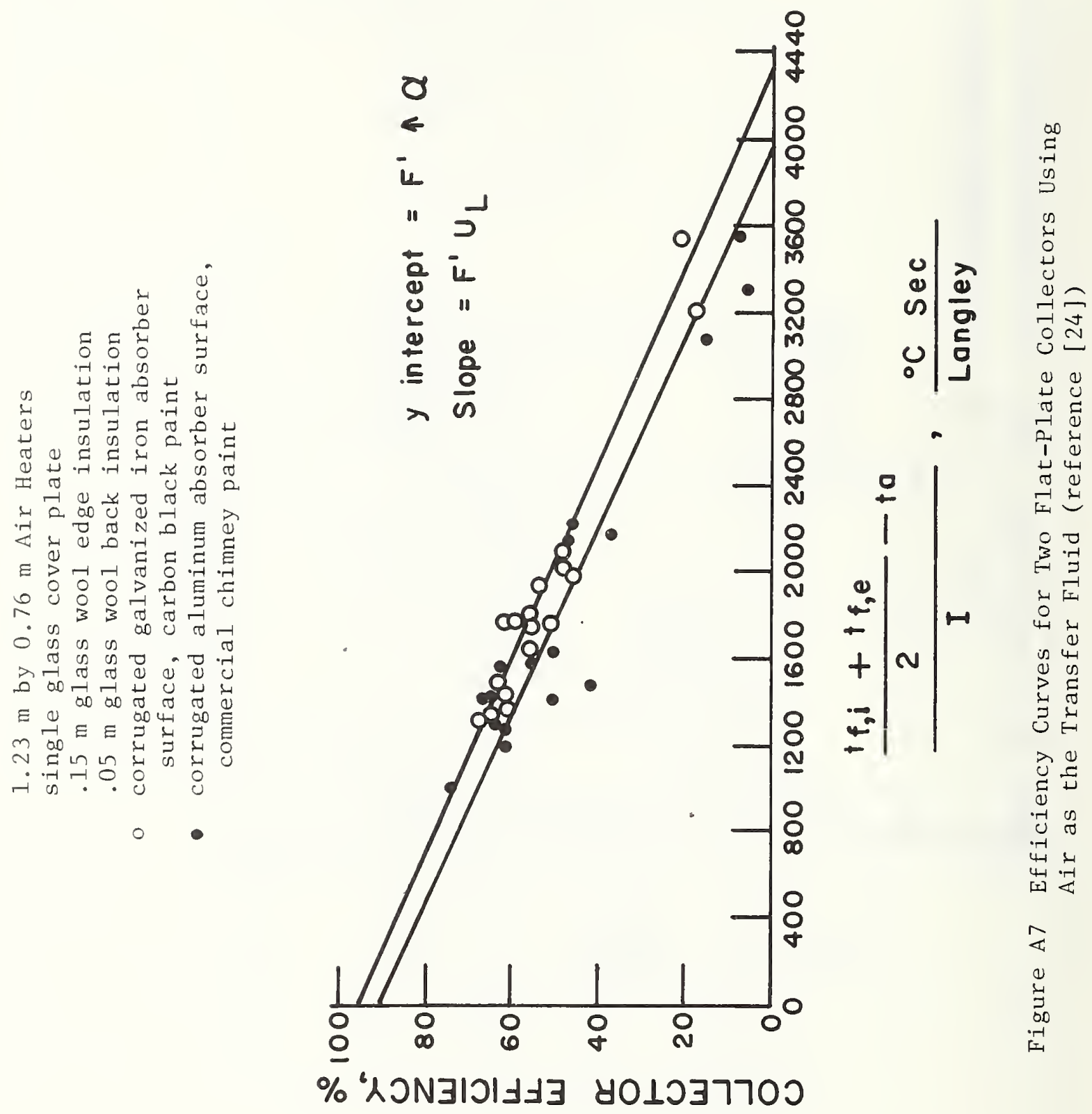

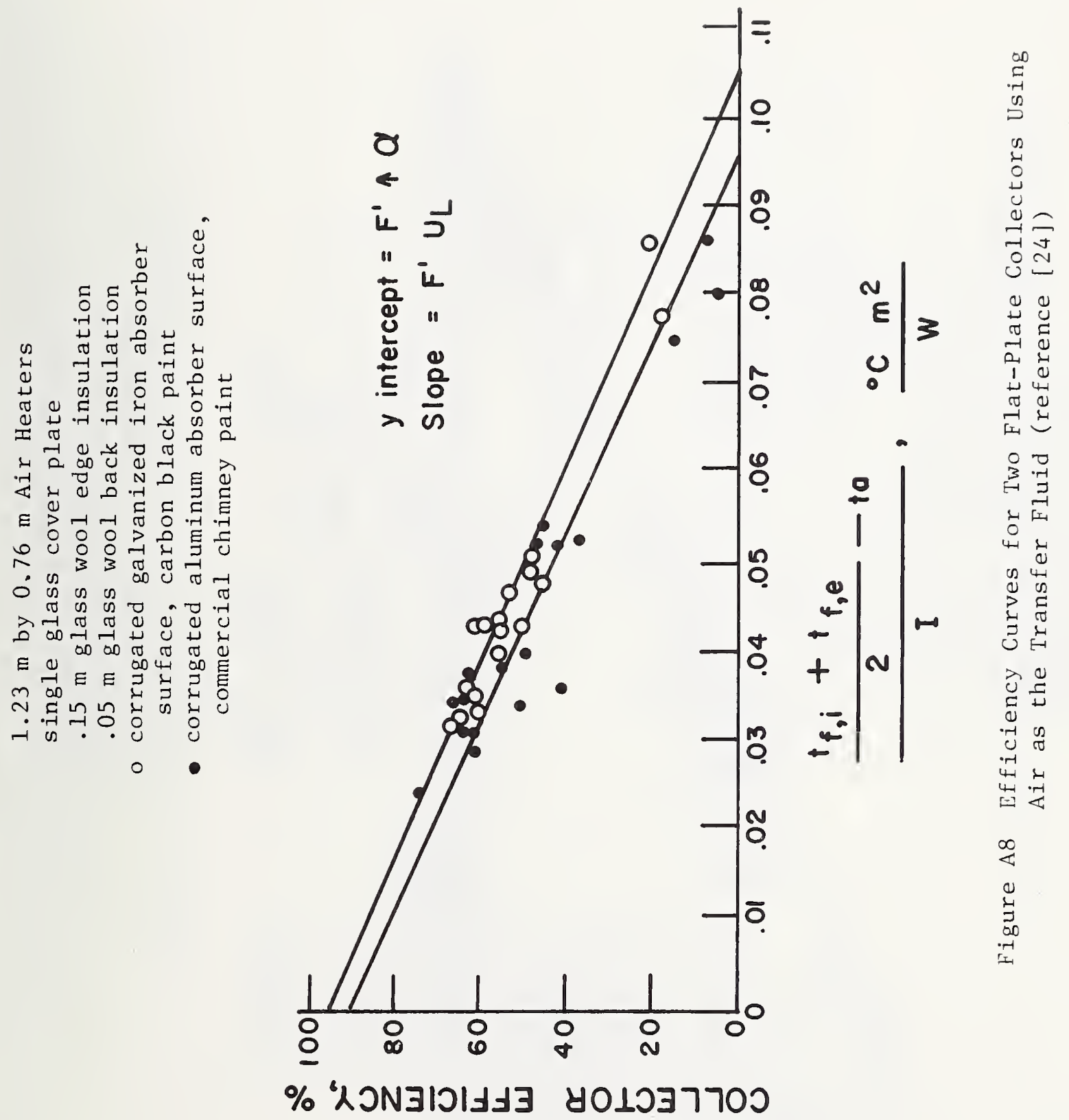


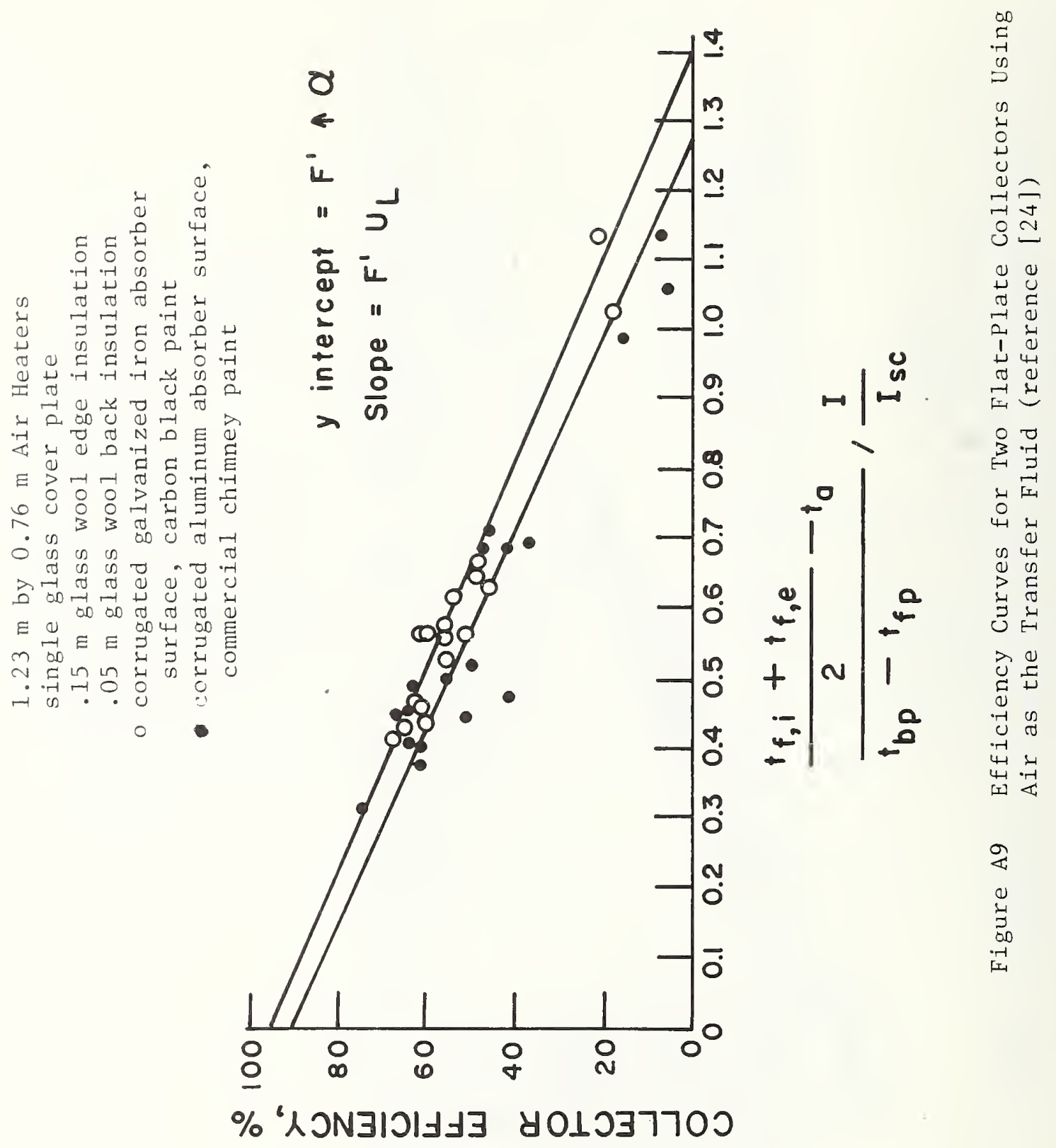



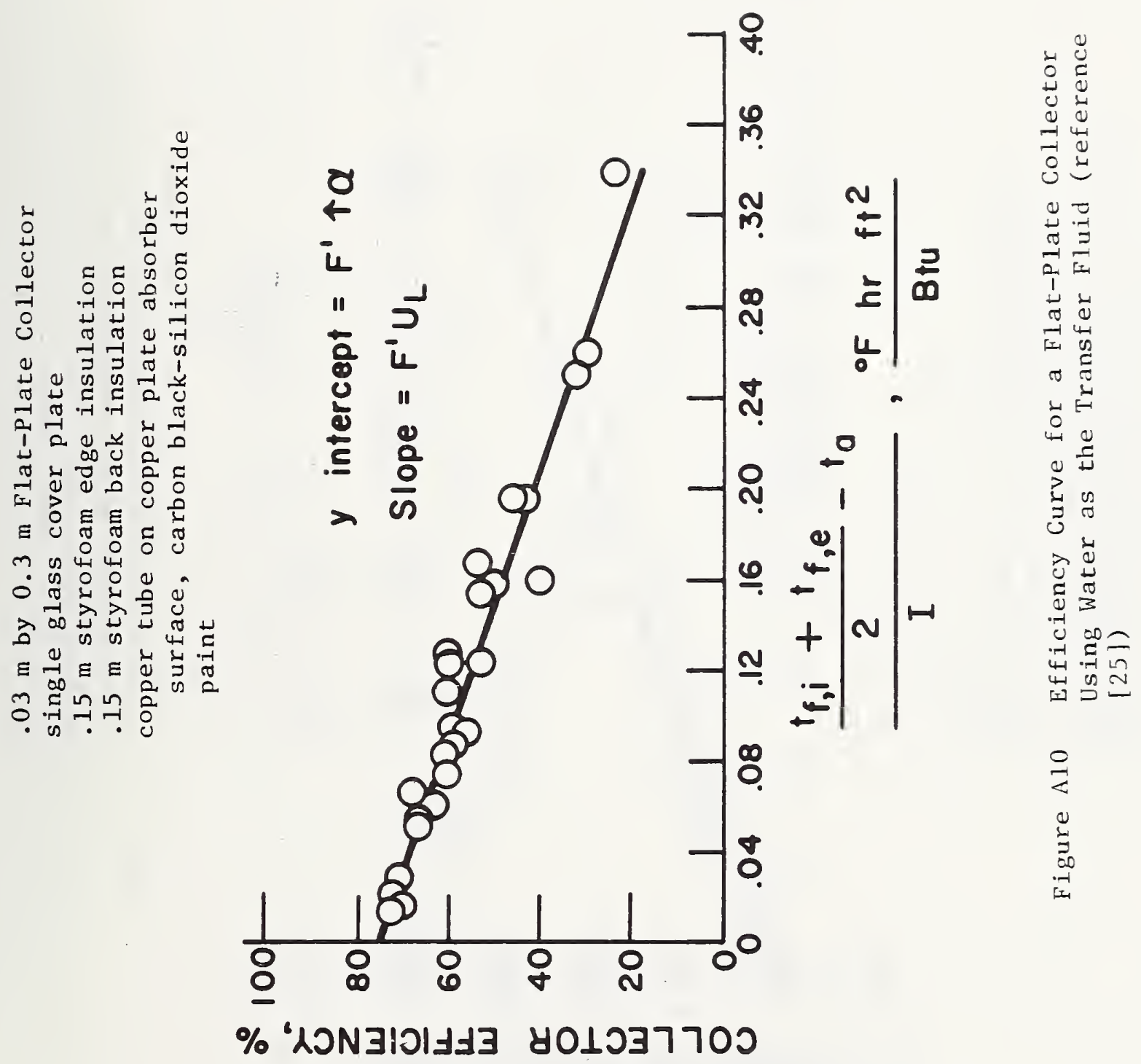

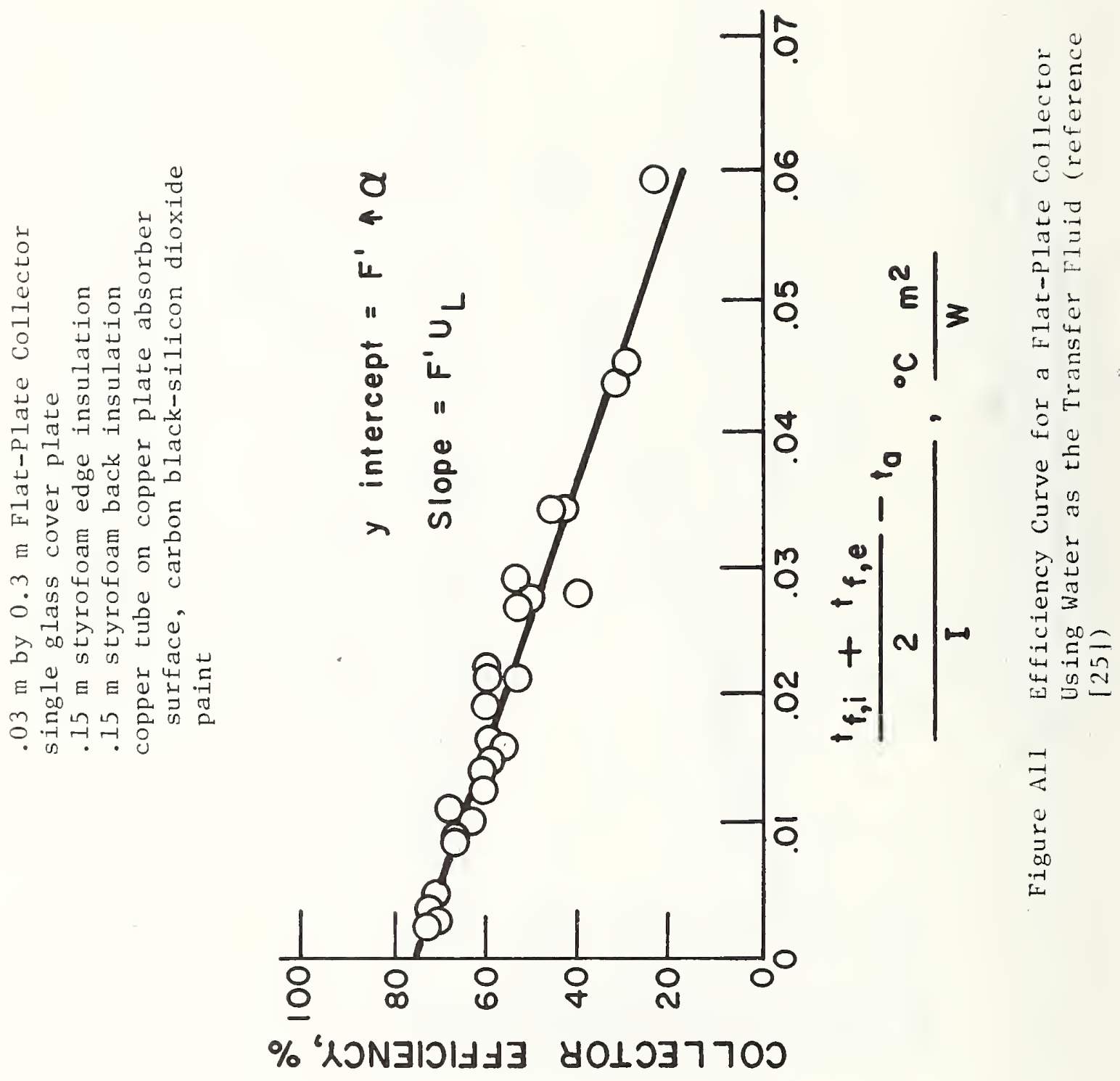

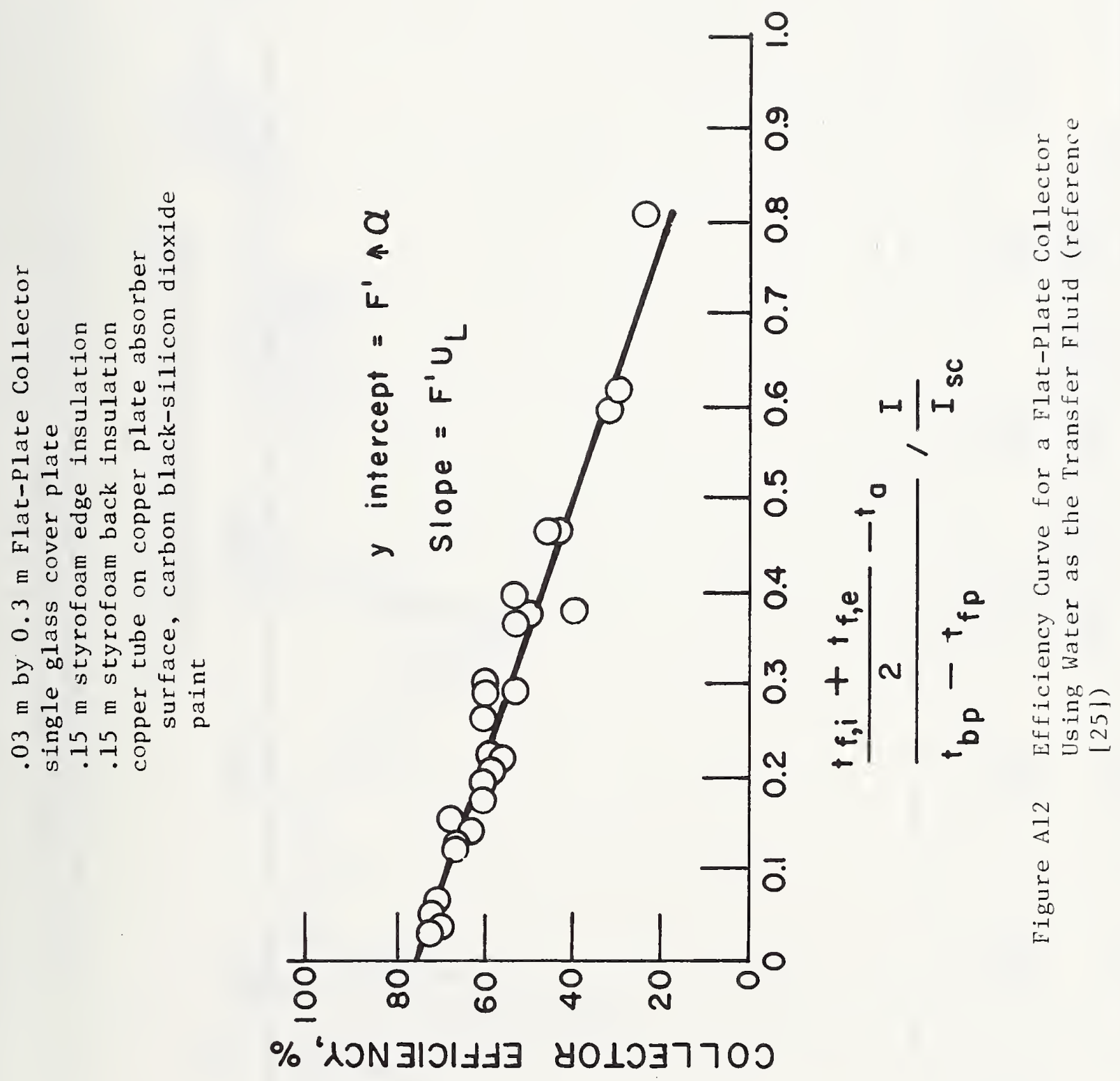


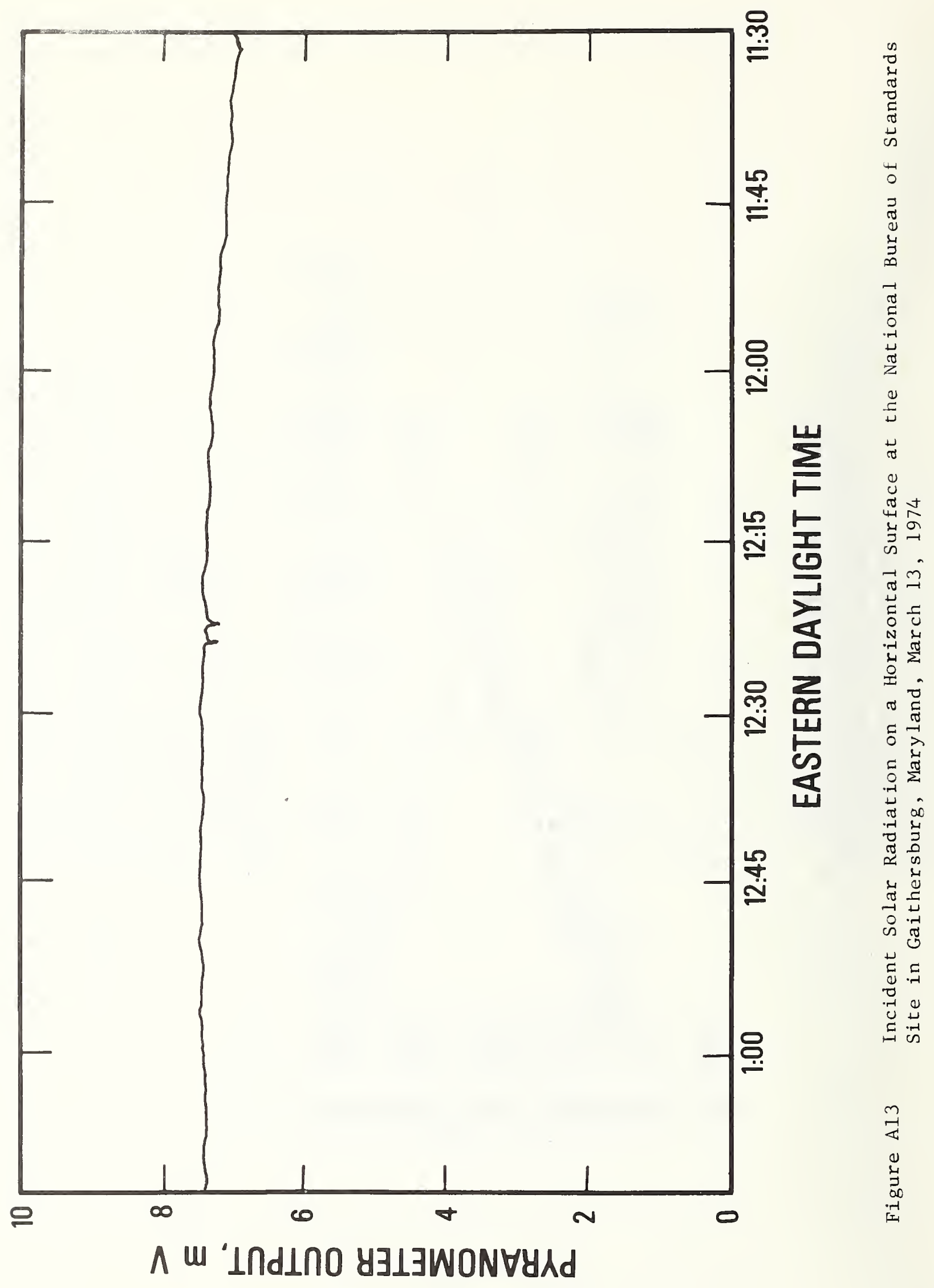




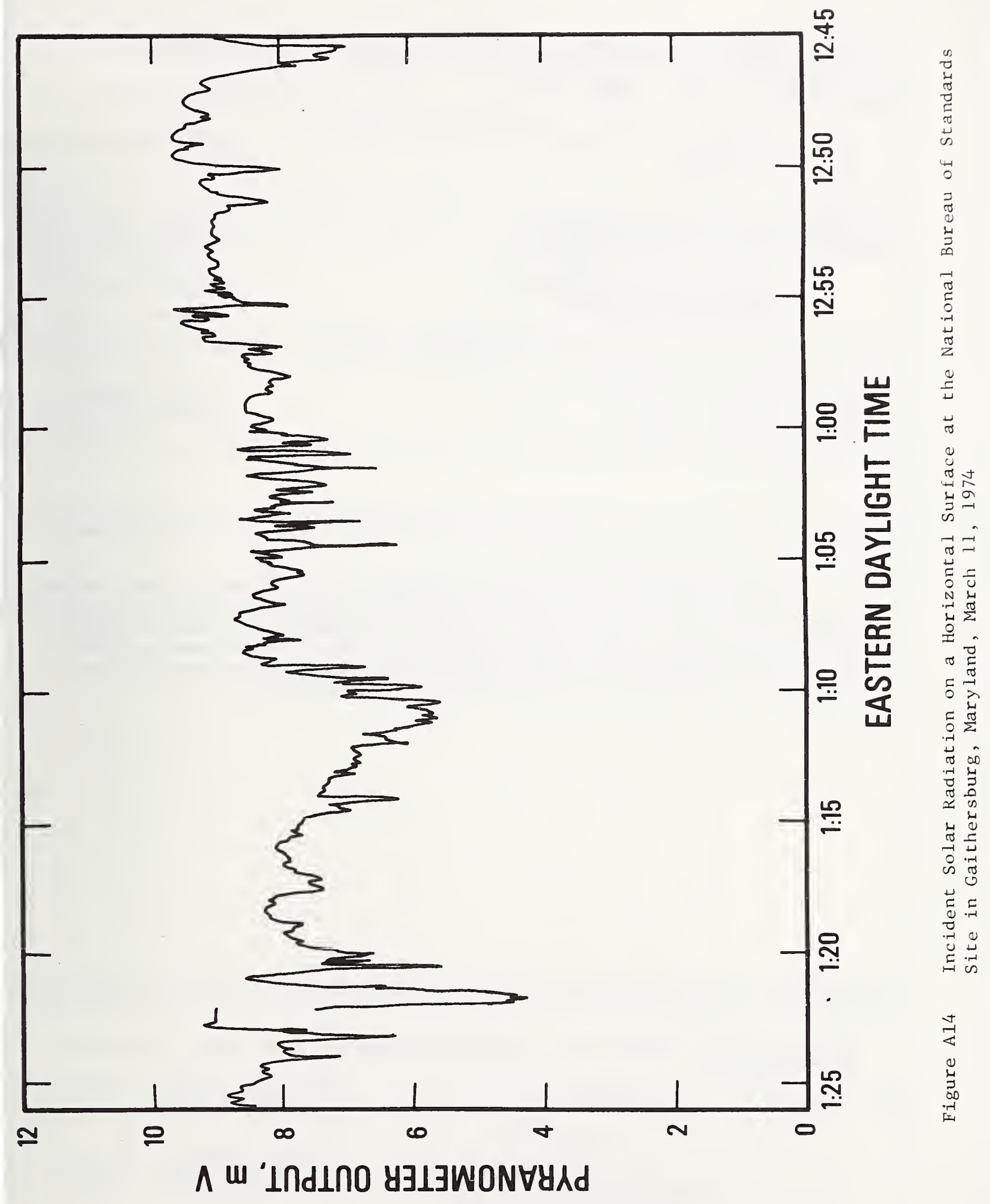




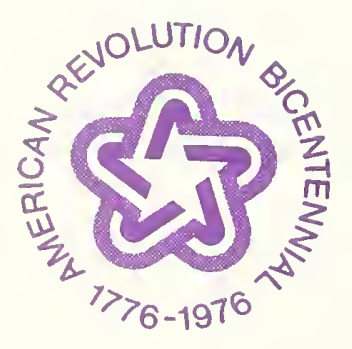

